\title{
Development of an aerosol microphysical module: Aerosol Two-dimensional bin module for foRmation and Aging Simulation (ATRAS)
}

\author{
H. Matsui ${ }^{1}$, M. Koike ${ }^{2}$, Y. Kondo ${ }^{2}$, J. D. Fast ${ }^{3}$, and M. Takigawa ${ }^{1}$ \\ ${ }^{1}$ Department of Environmental Geochemical Cycle Research, Japan Agency for Marine-Earth Science and Technology, \\ Kanagawa, Japan \\ ${ }^{2}$ Department of Earth and Planetary Science, Graduate School of Science, University of Tokyo, Tokyo, Japan \\ ${ }^{3}$ Pacific Northwest National Laboratory, Richland, Washington, USA
}

Correspondence to: H. Matsui (matsui@ jamstec.go.jp)

Received: 12 March 2014 - Published in Atmos. Chem. Phys. Discuss.: 28 April 2014

Revised: 27 August 2014 - Accepted: 27 August 2014 - Published: 30 September 2014

\begin{abstract}
Number concentrations, size distributions, and mixing states of aerosols are essential parameters for accurate estimations of aerosol direct and indirect effects. In this study, we develop an aerosol module, designated the Aerosol Two-dimensional bin module for foRmation and Aging Simulation (ATRAS), that can explicitly represent these parameters by considering new particle formation (NPF), black carbon (BC) aging, and secondary organic aerosol (SOA) processes. A two-dimensional bin representation is used for particles with dry diameters from $40 \mathrm{~nm}$ to $10 \mu \mathrm{m}$ to resolve both aerosol sizes (12 bins) and BC mixing states (10 bins) for a total of 120 bins. The particles with diameters between 1 and $40 \mathrm{~nm}$ are resolved using additional eight size bins to calculate NPF. The ATRAS module is implemented in the WRF-Chem model and applied to examine the sensitivity of simulated mass, number, size distributions, and optical and radiative parameters of aerosols to NPF, BC aging, and SOA processes over East Asia during the spring of 2009. The BC absorption enhancement by coating materials is about $50 \%$ over East Asia during the spring, and the contribution of SOA processes to the absorption enhancement is estimated to be 10-20\% over northern East Asia and 20-35\% over southern East Asia. A clear north-south contrast is also found between the impacts of NPF and SOA processes on cloud condensation nuclei (CCN) concentrations: NPF increases CCN concentrations at higher supersaturations (smaller particles) over northern East Asia, whereas SOA increases CCN concentrations at lower supersaturations (larger particles) over southern East Asia. The application of ATRAS in East Asia
\end{abstract}

also shows that the impact of each process on each optical and radiative parameter depends strongly on the process and the parameter in question. The module can be used in the future as a benchmark model to evaluate the accuracy of simpler aerosol models and examine interactions between NPF, $\mathrm{BC}$ aging, and SOA processes under different meteorological conditions and emissions.

\section{Introduction}

Atmospheric aerosols play an important role in Earth's climate system by scattering and absorbing solar radiation (direct effects) and by modifying the microphysical properties of clouds and precipitation (indirect effects). Estimates of these direct and indirect effects remain highly uncertain, and they are one of the largest uncertainties in predicting climate change (Ramanathan et al., 2001; Lohmann and Feichter, 2005; Bond et al., 2013; IPCC, 2013).

Accurate estimations of these effects through a model require good representations of aerosol number concentrations, size distributions, and mixing states because these parameters are essential for calculating aerosol absorption and scattering coefficients and for calculating the number concentrations of cloud droplets activated from aerosols (Jacobson, 2000; Ghan et al., 2011; Reddington et al., 2011). However, many of the existing three-dimensional aerosol models do not represent these aerosol parameters sufficiently. These models predict mass concentrations but diagnose size 
distributions, number concentrations, or both by assuming variable or predetermined lognormal size distributions. A model that can predict aerosol number concentrations, size distributions, and mixing states should be useful for reducing the uncertainties in the estimates of aerosol contributions to climate change.

Various physical and chemical processes play important roles in controlling the number concentrations, size distributions, and mixing states of aerosols in the atmosphere. New particle formation (NPF), which is the formation of ultrafine particles $(\sim 1 \mathrm{~nm}$ in diameter) and their subsequent growth, is considered to have a large impact on aerosol number concentrations and cloud condensation nuclei $(\mathrm{CCN})$ concentrations and ultimately on cloud droplet number concentrations and the indirect effects of aerosols (Kulmala et al., 2000, 2004, 2007; Spracklen et al., 2006, 2008, 2010; Merikanto et al., 2009; Makkonen et al., 2009, 2012). Aging processes (i.e., condensation, coagulation, and photochemical oxidation) of black carbon (BC) particles enhance their absorption efficiency and CCN activity, and they increase the heating rate of the atmosphere and the wet scavenging efficiency of $\mathrm{BC}$ and modify the microphysical properties of clouds (Jacobson, 2000, 2001; Bond et al., 2006, 2013; Stier et al., 2006; Moteki et al., 2007). Resolving externally mixed BC, internally mixed $\mathrm{BC}$, and $\mathrm{BC}$-free particles is essential for accurately estimating $\mathrm{BC}$ radiative and cloud microphysical effects (Oshima et al., 2009; Aquila et al., 2011; Matsui et al., 2013a). Organic aerosol (OA) formation, which has been severely underestimated in many existing threedimensional aerosol models (Heald et al., 2005, 2011; Matsui et al., 2009a; Spracklen et al., 2011), is also important in terms of the mass concentration and CCN activity of aerosols (Kanakidou et al., 2005; Zhang et al., 2007; Hallquist et al., 2009).

In our previous studies, we developed modules for NPF, $\mathrm{BC}$ aging, and secondary OA (SOA) processes individually using the Weather Research and Forecasting and Chemistry (WRF-Chem) model (Matsui et al., 2011, 2013a, b, 2014). These modules succeeded in explaining important aerosol properties related to number concentrations, size distributions, and mixing states of aerosols in the atmosphere. Our NPF-resolved aerosol module (Matsui et al., 2011) can calculate condensational growth and coagulation sink of nucleated particles with 20 aerosol size bins from $1 \mathrm{~nm}$ to $10 \mu \mathrm{m}$ in diameter, and the module reproduced the timing of NPF events in the Beijing region of China. Our BC mixing-state-resolved aerosol module (Matsui et al., 2013a) calculates BC aging processes using a two-dimensional aerosol bin representation $(12 \times 10$ bins) that resolves both aerosol sizes (from $40 \mathrm{~nm}$ to $10 \mu \mathrm{m}$ in diameter) and $\mathrm{BC}$ mixing states (pure-BC particles, $\mathrm{BC}$-free particles, and eight different internally mixed $\mathrm{BC}$ particles). This module reproduced the features of the $\mathrm{BC}$ mixing state observed by a single-particle soot photometer (SP2) during the Aerosol Radiative Forcing in East Asia (AFORCE) aircraft campaign, and it was used to evaluate the impact of the treatment of $\mathrm{BC}$ mixing state on radiative and microphysical properties of $\mathrm{BC}$ over the East Asian region. Our SOA scheme (Matsui et al., 2014), which is based on the volatility basis-set approach (Donahue et al., 2006; Jimenez et al., 2009), reproduced mass concentrations and temporal variations of OA over East Asia reasonably well.

Our previous studies showed the improvement of model performance for NPF, BC aging, and SOA processes by using a detailed aerosol model. A detailed model is useful, particularly when detailed aerosol parameters are compared between measurements and model simulations, because it is conceptually better (e.g., Korhola et al., 2014) and uses less assumption than a simple model. With the development of more advanced observational techniques, we need more detailed and sophisticated representations in aerosol models for comparisons.

In this study, we develop an aerosol module that can calculate NPF, BC aging, and SOA processes simultaneously. The module, designated the Aerosol Two-dimensional bin module for foRmation and Aging Simulation (ATRAS), is implemented in the WRF-Chem model. Few three-dimensional aerosol models can calculate NPF, BC aging, and SOA processes simultaneously (Yu et al., 2012). To our knowledge, ATRAS can calculate these processes simultaneously with the most detailed treatment of BC aging processes. Here, we describe the ATRAS module (Sect. 2) and present the first results of its application over East Asia to examine the sensitivity of mass, number, size distributions, and optical and radiative parameters of aerosols to NPF, BC aging, and SOA processes (Sect. 3).

\section{The two-dimensional bin module: ATRAS}

The ATRAS module is developed using the framework of the WRF-Chem model (version 3.4) (Grell et al., 2005; Skamarock et al., 2008), and it is used in combination with the Model for Simulating Aerosol Interactions and Chemistry (MOSAIC) aerosol module (Fast et al., 2006; Zaveri et al., 2008) (hereafter referred to as WRF-Chem/ATRASMOSAIC). We used the WRF-Chem/MOSAIC model in our previous studies (Matsui et al., 2009b, 2010, 2011, 2013a, b, 2014).

The ATRAS module uses 128 aerosol bins in total (Fig. 1). A two-dimensional bin representation is used for particles with dry diameters from $40 \mathrm{~nm}$ to $10 \mu \mathrm{m}$ to resolve both aerosol sizes and $\mathrm{BC}$ mixing states. As in our $\mathrm{BC}$ mixingstate-resolved aerosol module (Matsui et al., 2013a), the aerosol sizes from $40 \mathrm{~nm}$ to $10 \mu \mathrm{m}$ are divided into 12 bins, and the $\mathrm{BC}$ mixing state is divided into 10 bins using the fraction of the $\mathrm{BC}$ mass to the total aerosol mass concentrations under dry conditions. Within this size range, the module can resolve pure-BC particles (BC mass fraction >0.99), $\mathrm{BC}$-free particles $(\mathrm{BC}$ mass fraction $=0$ ), and eight different internally mixed $\mathrm{BC}$ particles (BC mass fractions of $0-0.1$, 


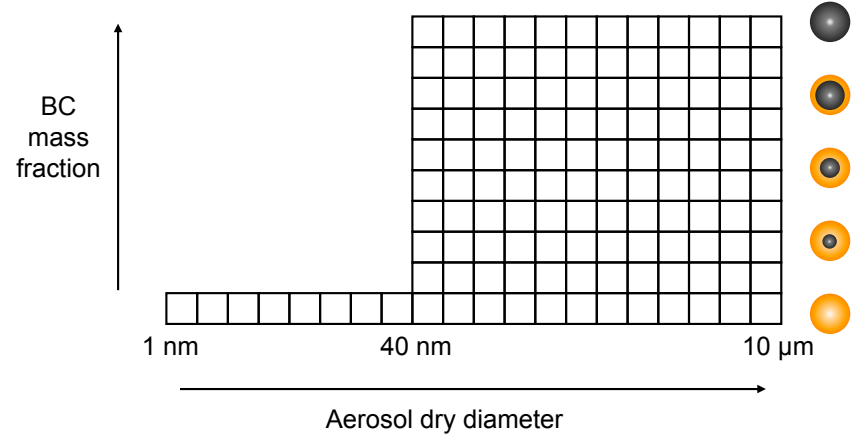

Figure 1. Aerosol bin representation used in the ATRAS module. Particles with dry diameters from $40 \mathrm{~nm}$ to $10 \mu \mathrm{m}$ are placed into two-dimensional bins. One dimension is aerosol dry diameter (12 bins from $40 \mathrm{~nm}$ to $10 \mu \mathrm{m}$ ) and the other is the fraction of BC mass relative to total aerosol mass concentration under dry condition (10 bins: pure-BC particles, $\mathrm{BC}$-free particles, and 8 different internally mixed $\mathrm{BC}$ particles). The particles with dry diameters from 1 to $40 \mathrm{~nm}$ are divided into eight size bins to calculate NPF.

$0.1-0.2,0.2-0.35,0.35-0.5,0.5-0.65,0.65-0.8,0.8-0.9$, and $0.9-0.99)$. The particles from 1 to $40 \mathrm{~nm}$ are resolved using eight size bins to calculate NPF. Particles in this size range are assumed to be BC-free. The module therefore uses 128 bins $(12 \times 10+8$ bins) to represent aerosol sizes, $\mathrm{BC}$ mixing states, and NPF processes. Mass concentrations of sulfate, nitrate, ammonium, BC, OA (sum of primary and secondary), dust, sodium, chloride, and aerosol water and number concentrations are traced in each aerosol bin. Aerosols in the aerosol phase (interstitial) and the cloud phase are treated separately using additional 128 bins for cloud-phase (activated) aerosols (in total 256 bins are used to represent aerosols).

Primary aerosol emissions (BC and $\mathrm{OA}$ in this study) are treated as pure-BC or BC-free particles from $40 \mathrm{~nm}$ to $10 \mu \mathrm{m}$. The uncertainty of mixing state treatment in emissions is described by Matsui et al. (2013a). Gas-phase chemistry is calculated by the SAPRC-99 mechanism (Carter, 2000) with modification for SOA precursors (Matsui et al., 2014). The particle formation (nucleation) rate at $1 \mathrm{~nm}$ is estimated by activation-type (e.g., Kulmala et al., 2006) or kinetic nucleation (e.g., Kuang et al., 2008) in the boundary layer and by a binary $\left(\mathrm{H}_{2} \mathrm{SO}_{4}\right.$-water) homogeneous nucleation (Wexler et al., 1994) in the free troposphere, as described by Matsui et al. (2011). In this study, we use the activation-type nucleation (nucleation rate at $1 \mathrm{~nm}$ is proportional to $\mathrm{H}_{2} \mathrm{SO}_{4}$ concentrations) with a constant rate coefficient of $2 \times 10^{-7} \mathrm{~s}^{-1}$, which was adopted in our previous studies (Matsui et al., 2011, 2013b). Condensation and evaporation are calculated by the MOSAIC module (Zaveri et al., 2005a, b, 2008). Aqueousphase chemistry is calculated by the scheme developed by Fahey and Pandis (2001). The shift of bins due to condensation, evaporation, and aqueous-phase chemistry is calculated by a two-moment (mass and number) advection scheme
(Simmel and Wurzler, 2006) for aerosol size bins and the moving-center approach (Jacobson, 1997) for mixing state bins, as described by Matsui et al. (2013a). Brownian coagulation within two-dimensional bins is calculated using the method of Matsui et al. (2013a), which is based on the semiimplicit method of Jacobson et al. (1994).

SOA processes are calculated by the volatility basis-set scheme with photochemical multigenerational oxidation of organic vapors by $\mathrm{OH}$ radicals (Matsui et al., 2014), which is similar in many respects to Shrivastava et al. (2011). This scheme uses nine volatility classes to represent semivolatile and intermediate volatility organic compounds (S/IVOCs). We consider the formation of first-generation oxidized VOCs (OVOCs) from nine lumped VOCs: alkanes (ALK4 and ALK5), olefins (OLE1 and OLE2), aromatics (ARO1 and $\mathrm{ARO} 2$ ), isoprene (ISOP), monoterpene (TERP), and sesquiterpene (SESQ). The mass yield of OVOCs from each lumped VOC is calculated with a $\mathrm{NO}_{\mathrm{x}}$-dependent four-product basis fit (Tsimpidi et al., 2010). S/IVOCs and OVOCs are oxidized to the volatility class with an order of magnitude lower effective saturation concentrations by $\mathrm{OH}$ radicals at a rate constant of $1 \times 10^{-11} \mathrm{~cm}^{3}$ molecule ${ }^{-1} \mathrm{~s}^{-1}$. Size-resolved OA condensation and evaporation are calculated using the method of Koo et al. (2003) by assuming gas-particle equilibrium partitioning (Schell et al., 2001). Dry deposition and wet deposition of both gaseous and aerosol species are calculated using the method adopted in the original WRF-Chem/MOSAIC model (Easter et al., 2004). Aerosol activation to cloud droplets is calculated on the basis of the method described by Abdul-Razzak and Ghan (2000) through the calculation of volume-averaged hygroscopicity and critical supersaturation for each aerosol bin (Matsui et al., 2011, 2013a). The values of hygroscopicity ( $\kappa$ ) for each aerosol species are given by Matsui et al. (2011). A $\kappa$ value of 0.14 is assumed for all the OA species used in the volatility basis-set scheme (Matsui et al., 2014). In Table 1, the schemes and the representation used in ATRASMOSAIC are summarized and compared with those of the original WRF-Chem/MOSAIC model. More details of the WRF-Chem/MOSAIC model and the MOSAIC module are described by Fast et al. (2006) and Zaveri et al. (2008), respectively. More details of the NPF, BC aging, and SOA schemes are described by Matsui et al. $(2011,2013 \mathrm{a}, \mathrm{b}$, 2014).

\section{Application of ATRAS-MOSAIC to East Asia}

\subsection{Simulation settings}

Our previous WRF-Chem simulations were conducted over East Asia during the A-FORCE aircraft campaign (21 March-26 April 2009) (Matsui et al., 2013a, b, 2014). In these studies, aerosol mass and number concentrations and their spatial and temporal variations were evaluated using 
Table 1. Summary of chemical schemes and representations adopted in ATRAS-MOSAIC and the original MOSAIC.

\begin{tabular}{lll}
\hline Item or chemical process & ATRAS-MOSAIC & Original MOSAIC \\
\hline Aerosol emission & $40 \mathrm{~nm}-10 \mu \mathrm{m}$ (pure BC, BC-free) & $40 \mathrm{~nm}-10 \mu \mathrm{m}$ (internally mixed) \\
Gas-phase chemistry & SAPRC99 with SOA precursors & CBM-Z \\
Photolysis & Fast-J & Fast-J \\
Number of total aerosol bins & 128 (maximum) & 8 \\
Number of aerosol size bins & 20 & 8 \\
Number of mixing state bins & 10 (maximum) & 1 \\
Condensation and evaporation & MOSAIC (2-D) & MOSAIC \\
Coagulation & Two-dimensional semi-implicit method & Semi-implicit method \\
Nucleation & Activation-type/kinetic nucleation & Binary homogeneous nucleation \\
& (PBL*) and binary homogeneous & at 40 nm \\
& nucleation (FT*) at 1 nm & \\
Organic aerosol formation & Volatility basis set & Primary organic aerosol only \\
CCN activation & Multiple hygroscopicities & Single hygroscopicity for each size bin \\
for each size bin & \\
Opueous-phase chemistry & Fahey and Pandis (2001) & Fahey and Pandis (2001) \\
Dry and wet deposition & Multiple mixing states for each size bin & Single mixing state for each size bin \\
\hline
\end{tabular}

* PBL, planetary boundary layer; FT, free troposphere.

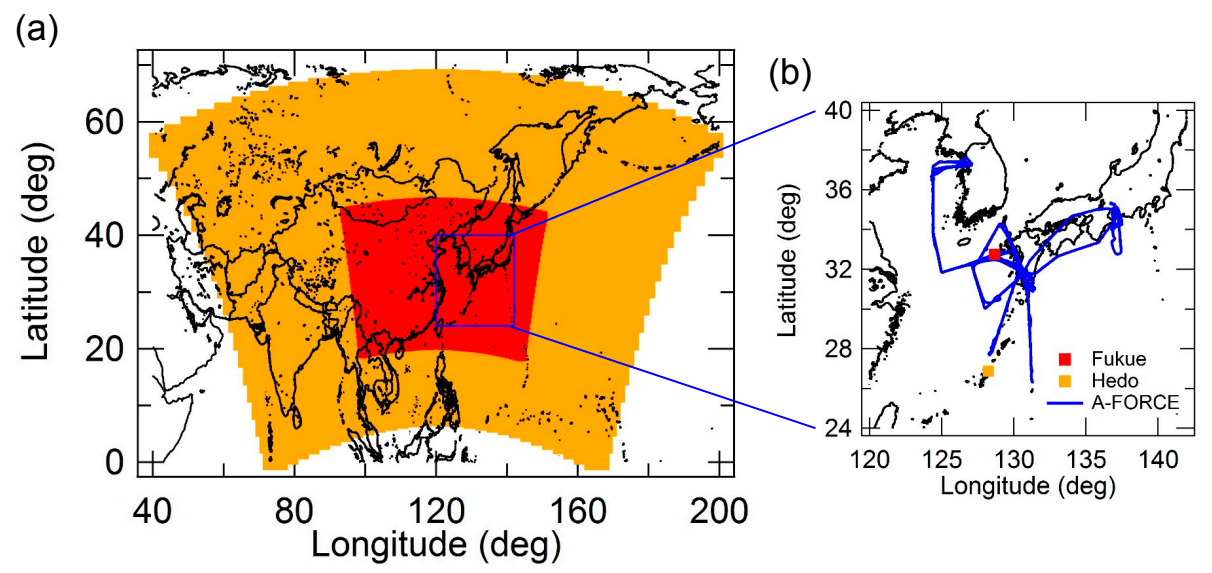

Figure 2. (a) Simulation domain used in this study. The simulations are conducted from 21 March to 26 April 2009 with horizontal resolutions of $360 \mathrm{~km}$ (outer domain, orange) and $120 \mathrm{~km}$ (inner domain). (b) The locations of surface measurements at the Fukue and Hedo sites and the flight tracks during the A-FORCE aircraft campaign, which are used to validate the model simulations in this study.

both aircraft and surface measurements. In this study, the ATRAS-MOSAIC model is applied to this region and period. Statistics are calculated for the period from 24 March to 26 April 2009 (34 days).

The simulation domain consists of an outer domain with a horizontal grid spacing of $360 \mathrm{~km}$ and an inner domain with a horizontal grid spacing of $120 \mathrm{~km}$; there are 13 vertical layers up to $100 \mathrm{hPa}$ (Fig. 2a). Because the ATRAS-MOSAIC module is computationally expensive, a relatively coarse grid resolution is used. However, our previous simulations using the same resolution reasonably well reproduced meteorological fields associated with synoptic-scale meteorological variations and resulting aerosol transport and variation processes during the A-FORCE period (Matsui et al., 2013a). The re- sults for the inner domain are described in this paper. We use the National Centers for Environmental Prediction Final Operational Global Analysis data for initial and boundary conditions and for nudging (free troposphere only) of meteorological fields. The meteorological schemes adopted in this study are similar to those used by Matsui et al. $(2009,2014)$.

In this study, aerosol optical and radiative parameters (shown in Sect. 3.4) are calculated offline using the method of Matsui et al. (2013a). Local aerosol optical properties are calculated using the Mie theory algorithm developed by Bohren and Huffman (1998). The shell-core treatment (BHCOAT) is used for internally mixed BC particles, while the code for well-mixed particles (BHMIE) is applied to pure BC and BC-free particles (Matsui et al., 2013a). The 
enhancement of $\mathrm{BC}$ absorption (the lens effect) by coating material (other than BC) is calculated in the BHCOAT. Radiative feedback of aerosols to meteorological parameters (e.g., temperature) is not considered in this study. The aerosol indirect effect is considered to calculate aerosol activation and removal processes theoretically. This treatment influences cloud microphysics and distribution, but we do not focus on these changes in this study. Radiative calculations are performed for clear-sky conditions (Sect. 3.4).

Emission inventories are also similar to those of Matsui et al. (2014): the anthropogenic and volcanic emissions of Streets et al. (2003), biomass burning emissions of the Global Fire Emissions Database version 3 (GFED3) (van der Werf et al., 2010), and the online biogenic emissions of the Model of Emissions of Gases and Aerosols from Nature version 2 (MEGAN2) (Guenther et al., 2006). A number median diameter of $50 \mathrm{~nm}$ and a standard deviation $(\sigma)$ of 2.0 are assumed as the size distribution of primary aerosol emissions (Matsui et al., 2013a). Emissions of coarse particles are not considered in this study.

We conduct nine model simulations (Table 2). The M10_SN simulation - which is the most detailed simulation with $\mathrm{BC}$ aging $(\mathrm{M})$ with $10 \mathrm{BC}$ mass fractions, SOA $(\mathrm{S})$, and NPF $(\mathrm{N})$ - is used as the benchmark simulation in this study. The M08_SN, M06_SN, M04_SN, and M01_SN simulations are runs with different numbers of $\mathrm{BC}$ mixing state bins and include NPF and SOA. BC mixing state bins are divided into $\mathrm{BC}$ mass fractions of $0,0-0.1,0.1-0.2,0.2-$ $0.5,0.5-0.8,0.8-0.9,0.9-0.99$, and $0.99-1.0$ in the M08_SN simulation; $0,0-0.2,0.2-0.5,0.5-0.8,0.8-0.99$, and $0.99-$ 1.0 in the M06_SN simulation; and 0, 0-0.8, 0.8-0.99, and 0.99-1.0 in the M04_SN simulation. These simulations are compared with the M10_SN simulation to examine the sensitivity of the mass and number concentrations and optical and radiative parameters of aerosols to the number of $\mathrm{BC}$ mixing state bins. The M10_N simulation (OA is from primary emissions only) is compared with the M10_SN simulation to examine the impact of SOA processes on $\mathrm{BC}$ mixing states. The M01_N, M01_S, and M01 simulations are conducted to determine the impact of NPF and SOA processes on aerosol properties. The M10_SN and M01 simulations are compared to understand the overall effects of NPF, BC aging, and SOA processes on aerosol properties. The M01_S simulation is nearly the same as the base simulation described by Matsui et al. (2014), except for the number of aerosol size bins (8 size bins for the simulation described in Matsui et al. (2014) versus 12 size bins in M01_S). The CPU time required for the M10_SN simulation is about $36 \mathrm{~h}$ per simulation day in our application (SGI ICE X (Intel Xeon E5-2670 2.6 GHz, SUSE Linux Enterprise Server 11SP1, Intel Composer XE 12)). Compared with the original eight-bin MOSAIC simulation, the computational costs are 14, 3.5, and 1.7 times greater in the M10_SN, M01_SN, and M01 simulations, respectively.
Table 2. List of model simulations.

\begin{tabular}{lllll}
\hline Simulation & $\begin{array}{l}\text { Number of } \\
\text { aerosol bins }\end{array}$ & BC mixing state & NPF & SOA \\
\hline M10_SN & 128 & On $(10$ bins $)$ & On & On \\
M10_N & 128 & On $(10$ bins $)$ & On & Off \\
M08_SN & 104 & On $(8$ bins $)$ & On & On \\
M06_SN & 80 & On $(6$ bins $)$ & On & On \\
M04_SN & 56 & On $(4$ bins $)$ & On & On \\
M01_SN & 20 & Off & On & On \\
M01_N & 20 & Off & On & Off \\
M01_S & 12 & Off & Off & On \\
M01 & 12 & Off & Off & Off \\
\hline
\end{tabular}

\subsection{Comparison with measurements}

We showed detailed validation results for various aerosol parameters obtained by surface and aircraft measurements (Fig. 2b) in our previous studies (Matsui et al., 2013a, b, c, 2014). Although the simulation setups in this study are not exactly the same as those in our previous studies (e.g., grid spacing, gas-phase chemistry mechanism, and amounts and size distributions of emissions), similar or better model performances are obtained for the following aerosol parameters in the benchmark M10_SN simulation (Fig. 3 and Figs. S1S3 in the Supplement): BC, sulfate, and OA mass concentrations at Fukue $\left(32.75^{\circ} \mathrm{N}, 128.68^{\circ} \mathrm{E}\right)$ and Hedo $\left(26.87^{\circ} \mathrm{N}\right.$, $128.25^{\circ} \mathrm{E}$ ) in Japan (outflow region from the Asian continent) (Matsui et al., 2013a, 2014), and mass and number concentrations of $\mathrm{BC}$ and scattering aerosols (other than $\mathrm{BC}$ ) and their vertical profiles, BC mixing states (the shell-to-core diameter ratio at a $\mathrm{BC}$ core diameter of $200 \mathrm{~nm}$ ), and aerosol number concentrations $(>10 \mathrm{~nm})$ in the boundary layer during the A-FORCE campaign (Matsui et al., 2013a, b). We note that the model performance improved for the shell-tocore diameter ratio during the A-FORCE campaign by considering SOA processes (Fig. 3). Details of the measurements during A-FORCE are given elsewhere (Moteki and Kondo, 2007, 2010; Kondo et al., 2011; Oshima et al., 2012; Moteki et al., 2012; Takegawa et al., 2013; Takami et al., 2005, 2007; Kanaya et al., 2013).

\subsection{Aerosol mass and number concentrations and size distributions}

The spatial distributions of period-averaged concentrations of $\mathrm{PM}_{2.5}$ (particulate matter smaller than $2.5 \mu \mathrm{m}$ in diameter) in the M10_SN and M01 simulations at an altitude of about $1 \mathrm{~km}$ (sigma level of 0.895) are shown in Fig. $4 \mathrm{a}$ and $\mathrm{b}$, and statistics are shown in Table 3. Period-averaged values are calculated using the data at 12:00 LT (03:00 UTC) during the simulation periods (24 March-26 April). The conclusions obtained in this section do not change, even when using the data at night (00:00 LT) (not shown). 
Observation Simulation (M10 SN)

Simulation (M10_N) $\quad$ Simulation (M01)
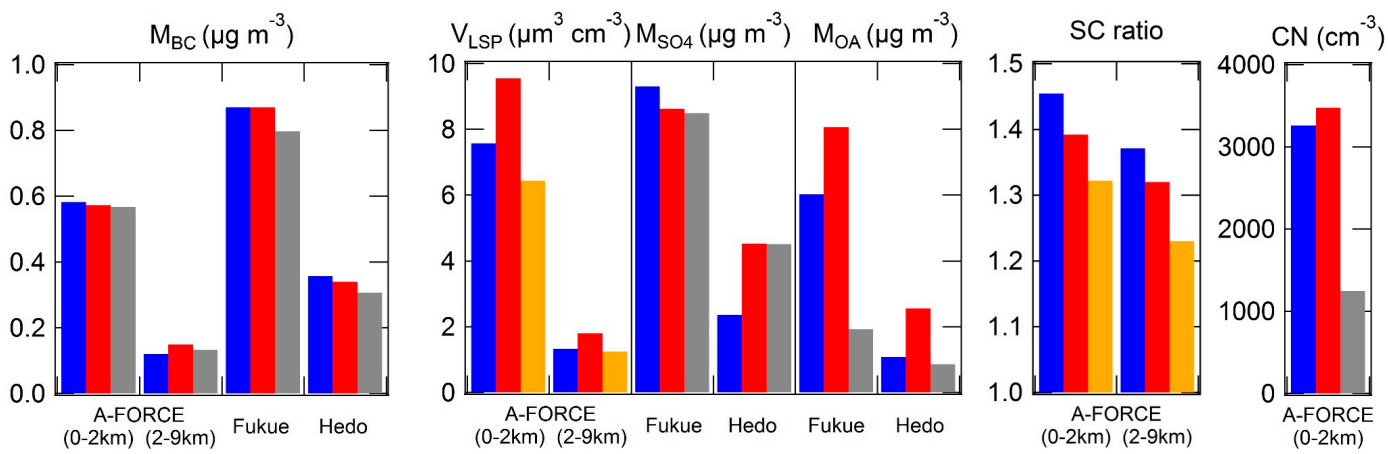

Figure 3. Comparison of the model simulation results with the observed average mass concentrations of $\mathrm{BC}\left(M_{\mathrm{BC}}\right)$, sulfate $\left(M_{\mathrm{SO}_{4}}\right)$, and organic aerosols $\left(M_{\mathrm{OA}}\right)$, the volume concentration of light-scattering particles $\left(V_{\mathrm{LSP}}\right)$, the shell-to-core diameter ratio at a $\mathrm{BC}$ core diameter of $200 \mathrm{~nm}$ (SC ratio), and the number concentration of Aitken-mode particles $(10-130 \mathrm{~nm})(\mathrm{CN})$. The simulated aerosol concentrations are chosen from the horizontal and vertical grids closest to each site (for surface measurements at Fukue and Hedo) or flight track (for aircraft measurements during A-FORCE).

(a)

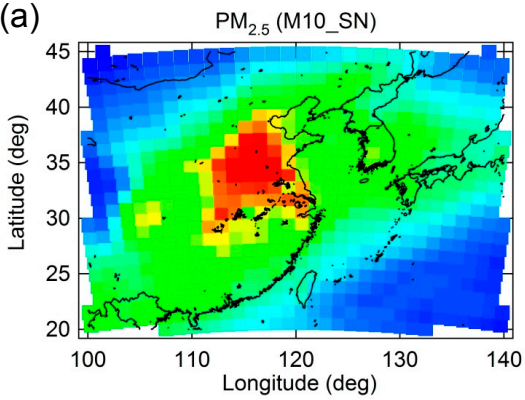

(c)

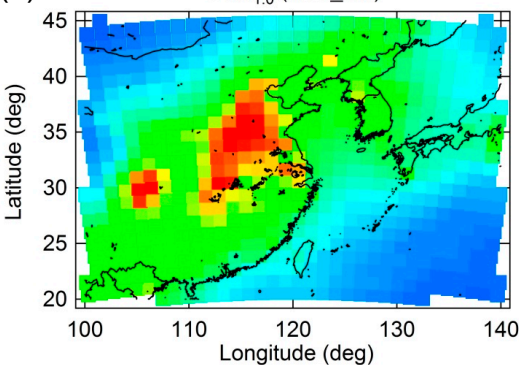

(e)

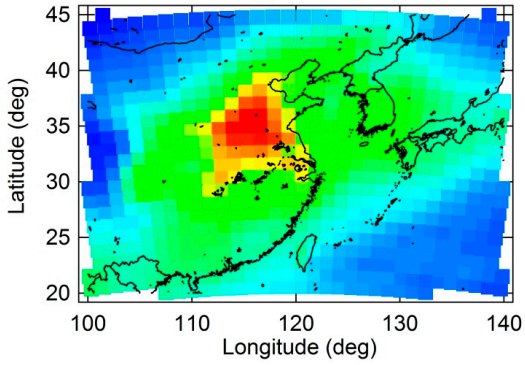

(b)
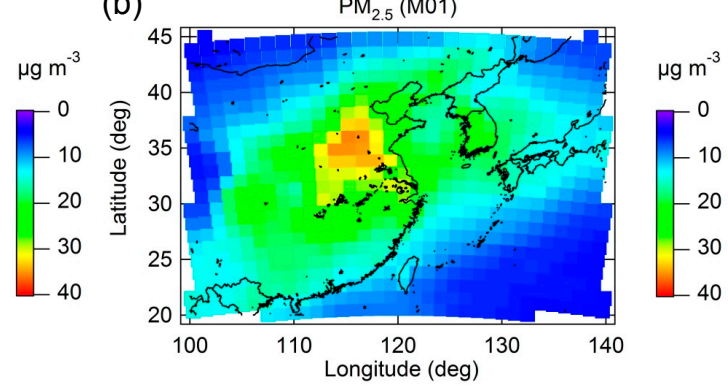

(d)
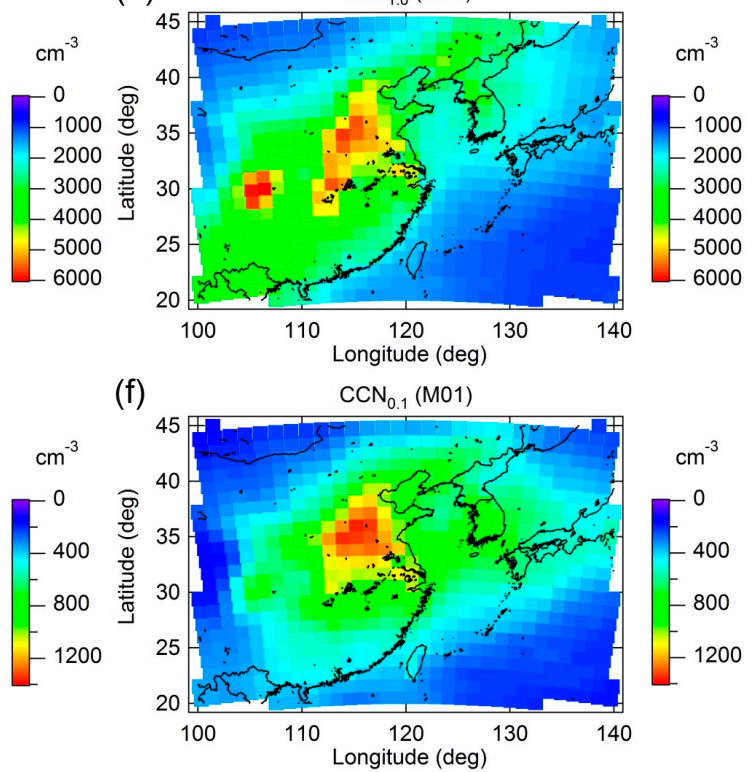

(f)

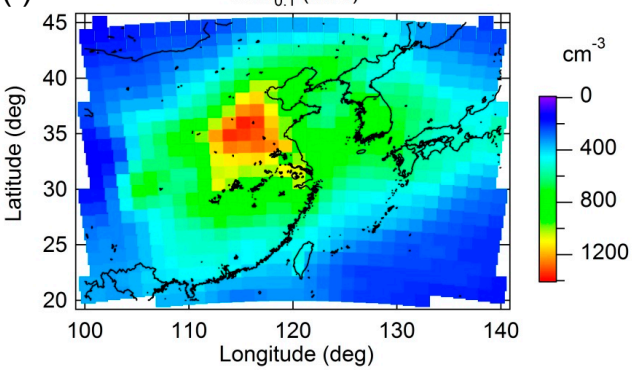

Figure 4. The period-averaged $\mathrm{PM}_{2.5}$ (a) M10_SN and (b) M01 runs, $\mathrm{CCN}$ concentrations at supersaturations of $1 \%\left(\mathrm{CCN}_{1.0}\right)$ (c) M10_SN and (d) M01 runs, and CCN concentrations at supersaturations of $0.1 \%\left(\mathrm{CCN}_{0.1}\right)$ (e) M10_SN and (f) M01 runs at a sigma level of 0.895 $(\sim 1 \mathrm{~km})$. Period-averaged values are calculated using the data at 12:00 LT (03:00 UTC) between 24 March and 26 April. 
Table 3. Period- and domain-averaged aerosol mass and number concentrations at an altitude of about $1 \mathrm{~km}$ (sigma level of 0.895$)$ at noon.

\begin{tabular}{lllllllllll}
\hline Parameter & Unit & M10_SN & M10_N & M08_SN & M06_SN & M04_SN & M01_SN & M01_N & M01_S & M01 \\
\hline $\mathrm{PM}_{2.5}$ & $\mu \mathrm{g} \mathrm{m}^{-3}$ & 15.1 & 12.1 & 15.1 & 15.2 & 15.1 & 15.1 & 12.1 & 15.0 & 12.1 \\
$\mathrm{BC}$ & $\mu \mathrm{g} \mathrm{m}^{-3}$ & 0.463 & 0.469 & 0.463 & 0.460 & 0.449 & 0.422 & 0.422 & 0.421 & 0.422 \\
$\mathrm{OA}$ & $\mu \mathrm{g} \mathrm{m}^{-3}$ & 4.30 & 1.43 & 4.31 & 4.32 & 4.30 & 4.31 & 1.44 & 4.30 & 1.45 \\
$\mathrm{SO}_{4}$ & $\mu \mathrm{g} \mathrm{m}^{-3}$ & 3.84 & 3.79 & 3.85 & 3.84 & 3.83 & 3.84 & 3.80 & 3.82 & 3.80 \\
$\mathrm{NH}_{4}$ & $\mu \mathrm{g} \mathrm{m}^{-3}$ & 1.89 & 1.87 & 1.89 & 1.89 & 1.88 & 1.88 & 1.87 & 1.87 & 1.87 \\
$\mathrm{NO}_{3}$ & $\mu \mathrm{g} \mathrm{m}^{-3}$ & 1.72 & 1.71 & 1.71 & 1.71 & 1.69 & 1.68 & 1.68 & 1.68 & 1.68 \\
$\mathrm{CCN}_{1.0}$ & $\mathrm{~cm}^{-3}$ & 2434 & 2409 & 2438 & 2446 & 2443 & 2469 & 2472 & 2063 & 2061 \\
$\mathrm{CCN}_{0.2}$ & $\mathrm{~cm}^{-3}$ & 1079 & 968 & 1081 & 1083 & 1079 & 1088 & 991 & 1034 & 959 \\
$\mathrm{CCN}_{0.1}$ & $\mathrm{~cm}^{-3}$ & 498 & 427 & 498 & 499 & 497 & 495 & 425 & 491 & 430 \\
\hline
\end{tabular}

The period- and domain-averaged $\mathrm{PM}_{2.5}$ concentrations are 15.1 and $12.1 \mu \mathrm{g} \mathrm{m}^{-3}$ in the M10_SN and M01 simulations, respectively. The higher $\mathrm{PM}_{2.5}$ concentrations in the M10_SN simulation (about $25 \%$ higher) are mostly due to SOA processes considering that the $\mathrm{PM}_{2.5}$ concentrations are different between the simulations with and without SOA processes (Table 3). The treatment of BC mixing state and NPF has a negligible impact on the period-averaged $\mathrm{PM}_{2.5}$ in our simulations. As emissions of coarse particles are not considered in this study (Sect. 3.1), most of $\mathrm{PM}_{2.5}$ is $\mathrm{PM}_{1}$ in our simulation: the period- and domain-averaged $\mathrm{PM}_{1}$ concentrations are $14.7 \mu \mathrm{g} \mathrm{m}^{-3}$ in the M10_SN simulation.

$\mathrm{BC}$ mass concentrations are influenced by the treatment of the $\mathrm{BC}$ mixing state (Table 3). BC mass concentration in the M10_SN simulation is higher than that in the M01_SN simulation because pure $\mathrm{BC}$ is explicitly resolved in the M10_SN simulation, whereas all $\mathrm{BC}$ is treated as internally mixed particles in the M01_SN simulation, resulting in a higher wet removal efficiency (Matsui et al., 2013a). BC concentrations in the M08_SN and M06_SN simulations are nearly the same as those in the benchmark M10_SN simulation. These two simulations can explain more than $90 \%$ of the total effect of $\mathrm{BC}$ mixing state (Table 3 ). The percentage is calculated from the difference in the $\mathrm{BC}$ mass concentrations between the M08_SN (or M06_SN) and M01_SN simulations relative to the difference between the M10_SN and M01_SN simulations. BC concentration in the M04_SN simulation is also generally consistent with that in the benchmark simulation: the M04_simulation can explain about $70 \%$ of the total effect of the $\mathrm{BC}$ mixing state. These results suggest that the simulations with four or more mixing state bins can explain the actual $\mathrm{BC}$ mixing state effect reasonably well in terms of the $\mathrm{BC}$ mass concentrations in the boundary layer. The treatments of NPF and SOA have a negligible impact on the period-averaged $\mathrm{BC}$ mass concentrations in our simulations.

OA mass concentrations differ substantially (by a factor of 3) between the simulations with and without SOA processes. The period- and domain-averaged OA concentrations are about 4.3 and $1.5 \mu \mathrm{g} \mathrm{m}^{-3}$ in the simulations with and without SOA processes, respectively (Table 3 ).
The CCN concentrations for two given supersaturations of $1.0 \%\left(\mathrm{CCN}_{1.0}\right)$ and $0.1 \%\left(\mathrm{CCN}_{0.1}\right)$ are calculated based on Köhler theory (Matsui et al., 2011). The spatial distributions of the period-averaged $\mathrm{CCN}_{1.0}$ for the M10_SN and M01 simulations at an altitude of about $1 \mathrm{~km}$ are shown in Fig. $4 \mathrm{c}$ and d. The $\mathrm{CCN}_{1.0}$ distributions in the M10_SN (M01) simulations are generally similar to those in the simulations with (without) NPF in Matsui et al. (2013b), although some model setups differ between Matsui et al. (2013b) and this study (e.g., grid resolution and gas-chemistry mechanism). Period- and domain-averaged $\mathrm{CCN}_{1.0}$ concentrations increase by $18 \%$ when both NPF and SOA processes are included (Table 3 ). The spatial distributions of the periodaveraged $\mathrm{CCN}_{0.1}$ are shown in Fig. $4 \mathrm{e}$ and $\mathrm{f}$. The period- and domain-averaged $\mathrm{CCN}_{0.1}$ concentrations increase by $16 \%$ when both NPF and SOA processes are included (Table 3). The treatment of $\mathrm{BC}$ mixing state is not particularly important for either $\mathrm{CCN}_{1.0}$ or $\mathrm{CCN}_{0.1}$ concentrations.

$\mathrm{dCCN}$ is defined as the difference in the $\mathrm{CCN}$ concentrations between M01_N and M01 (an index of the importance of NPF) or between M01_S and M01 (an index of the importance of SOA). There is a clear contrast in the importance between NPF and SOA processes. NPF increases $\mathrm{CCN}_{1.0}$ concentrations considerably, whereas SOA makes only a minor contribution to the increase in $\mathrm{CCN}_{1.0}$ concentrations (Fig. 5a and b). The increase in $\mathrm{CCN}_{1.0}$ concentrations due to NPF is distributed mainly over the northern part of the simulation domain (northern and central China, Korea, and Japan; Fig. 5a). This result is consistent with the results reported by Matsui et al. (2013b), who showed a clear northsouth contrast in the NPF frequency over East Asia (Fig. S4 in the Supplement). In contrast, SOA is much more important for $\mathrm{CCN}_{0.1}$ concentrations, whereas the impact of NPF on $\mathrm{CCN}_{0.1}$ concentrations is limited (Fig. $5 \mathrm{c}$ and d). The increase in $\mathrm{CCN}_{0.1}$ concentrations due to SOA is mainly seen over the southern part of the simulation domain (Southeast Asia and southern China; Fig. 5d), where SOA concentrations and their ratio to preexisting aerosols are high (e.g., SOA / BC ratio in Fig. S4 in the Supplement). These results show that NPF is an important factor for increasing $\mathrm{CCN}$ 


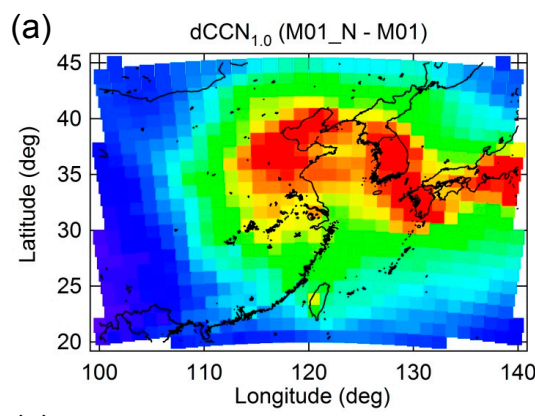

(c)

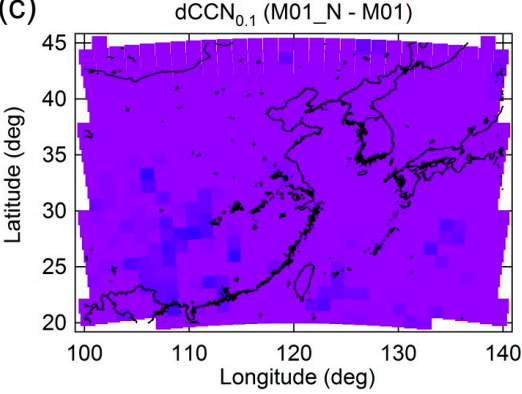

(b)

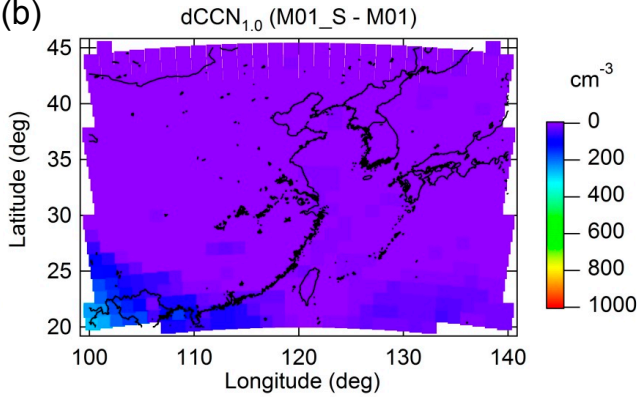

(d)
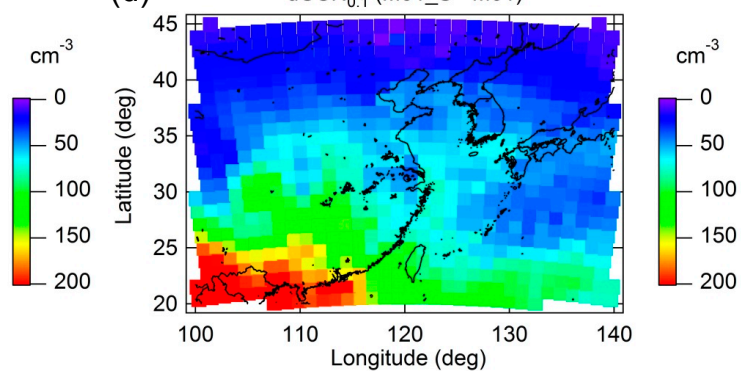

Figure 5. The period-averaged dCCN concentrations at a sigma level of $0.895(\sim 1 \mathrm{~km})$. dCCN is defined as the difference in the CCN concentration between M01_N and M01 (left panels, (a) $\mathrm{CCN}_{1.0}$ and (c) $\mathrm{CCN}_{0.1}$ ) or between M01_S and M01 (right panels, (b) CCN 1.0 and (d) $\mathrm{CCN}_{0.1}$ ). dCCN between M01_N (M01_S) and M01 can be used as a measure of the importance of NPF (SOA).
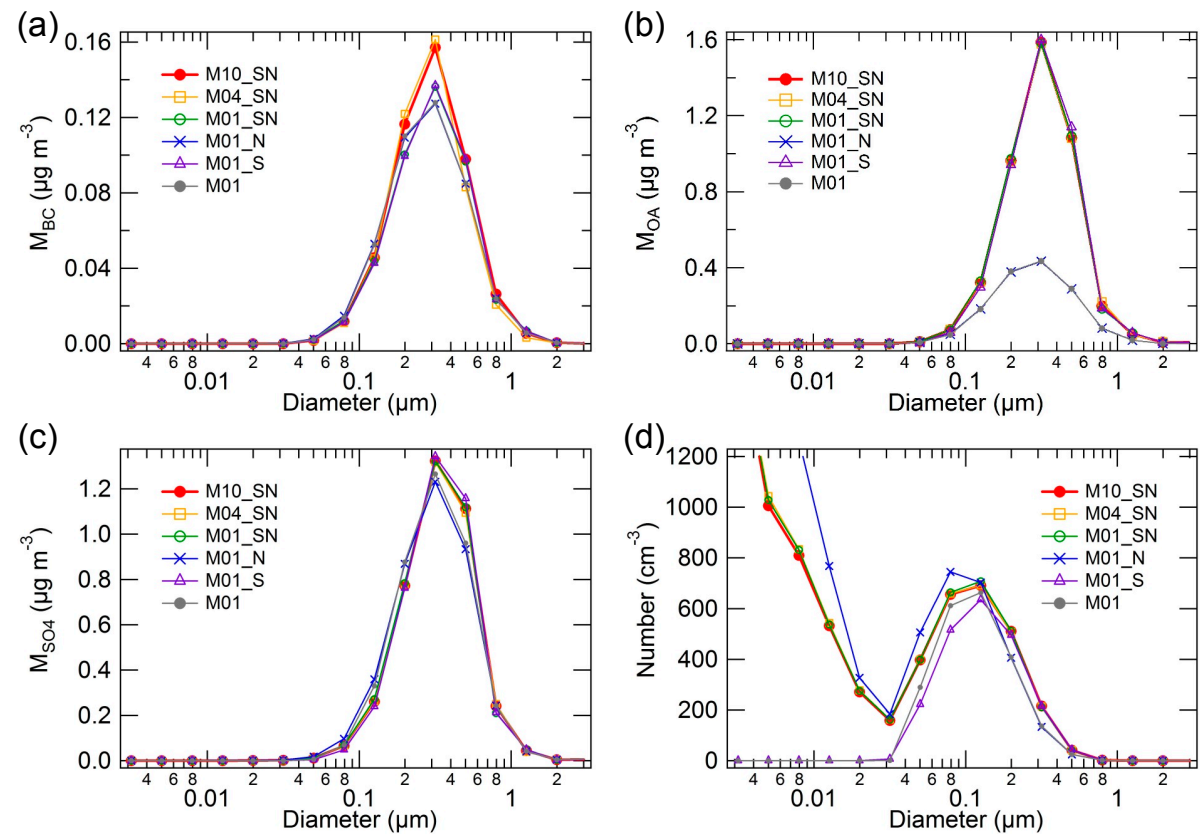

Figure 6. The period- and domain-averaged size distributions of (a) BC, (b) OA, and (c) sulfate mass concentrations and (d) number concentrations at a sigma level of $0.895(\sim 1 \mathrm{~km})$ in six simulations (the simulations are defined in Table 2).

concentrations at higher supersaturations (smaller particles) over northern East Asia, whereas SOA is an important factor for increasing CCN concentrations at lower supersaturations (larger particles) over southern East Asia. This difference might also imply that NPF and SOA processes have spatially different influences on cloud microphysical proper- ties over East Asia, although we do not focus on the indirect effects of aerosols in this study.

An increase in $\mathrm{BC}$ mass concentrations at an altitude of about $1 \mathrm{~km}$ is seen for particles of around $100-500 \mathrm{~nm}$ in the accumulation mode when the $\mathrm{BC}$ mixing state is resolved (M10_SN and M04_SN in Fig. 6a). SOA processes increase 
OA mass concentrations of around 100-500 nm with a shift to a larger size distribution (Fig. 6b). Total (bulk) mass concentrations of inorganic species are not particularly influenced by NPF, BC aging, or SOA processes (Table 3), but the size distributions of these species are shifted to larger sizes, mainly due to SOA processes (Fig. 6c). Number size distribution is influenced by both NPF and SOA processes (Fig. 6d). NPF has a large impact on the number concentrations of particles less than $100 \mathrm{~nm}$ in diameter (e.g., comparing the M01_N and M01 simulations), although condensation is the dominant process in terms of mass transfer from gas to the aerosol phase (the mass fraction of sulfate between 1 and $40 \mathrm{~nm}$ is only $0.07 \%$ of total sulfate mass on period and domain average at $1 \mathrm{~km}$ ). OA formation shifts the size distribution to larger sizes (e.g., comparing the M01_S and M01 simulations), with the increase in the number concentrations of particles of around $200-400 \mathrm{~nm}$ and the decrease in the number concentrations of particles of around 30-100 nm. The combined effects of NPF and SOA are reflected in the benchmark simulation (M10_SN).

Sensitivity simulations with 4 and 6 NPF bins between 1 and $40 \mathrm{~nm}$ show that they can capture the growth of nucleated particles and absolute number concentrations and their size distributions less than $40 \mathrm{~nm}$ in diameter reasonably well (Fig. S5 in the Supplement). These results suggest that four NPF bins between 1 and $40 \mathrm{~nm}$ may be sufficient for future applications. We focused on the period-averaged contributions of individual processes in this section, but their impacts could be much larger locally and temporarily. For example, while BC concentration in the M10_SN simulation is about $20 \%$ higher than that in the M01_SN simulation on periodand domain average, the concentration is more than $40 \%$ higher at particular places and times (Fig. S6 in the Supplement). Even though the impact of a process is small on period- and domain average (the concentration ratio is about 1.0 in Fig. S6 in the Supplement), the process can contribute to an increase or decrease in mass and/or number concentrations at particular places and times (Fig. S6 in the Supplement).

The vertical profiles of $\mathrm{CCN}$ and mass concentrations show that the features obtained at an altitude of about $1 \mathrm{~km}$ (layer 4) are seen at all levels (Fig. 7): $\mathrm{OA}$ and $\mathrm{CCN}_{0.1}$ concentrations are higher in the simulations with the OA formation scheme, BC mass concentrations are higher in the simulations that resolve mixing states, and $\mathrm{CCN}_{1.0}$ concentrations are higher in the simulations with NPF.

\subsection{Aerosol optical and radiative parameters}

Period-averaged optical and radiative parameters are calculated using the data at 12:00 LT during the simulation period (24 March-26 April). We focus on column aerosol optical depth (AOD), column absorption AOD (AAOD), singlescattering albedo (SSA) at $1 \mathrm{~km}$, heating rate by aerosols at
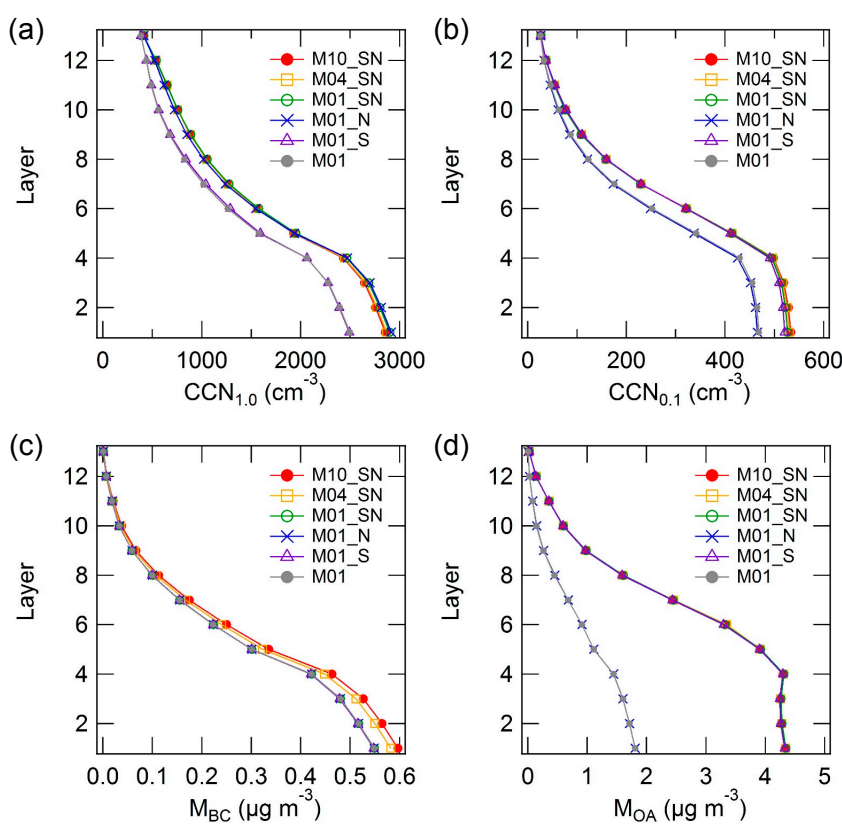

Figure 7. The period- and domain-averaged vertical profiles of (a) $\mathrm{CCN}_{1.0}$, (b) $\mathrm{CCN}_{0.1}$, (c) $\mathrm{BC}$ mass, and (d) OA mass concentrations in six simulations.

$1 \mathrm{~km}$, and change in downward solar flux by aerosols at the surface. The statistics are shown in Table 4.

Period- and domain-averaged AOD is increased by $26 \%$ by SOA processes (Table 4). The impact of NPF and BC aging processes on $\mathrm{AOD}$ is negligible in our simulations.

The treatment of BC mixing state is important for AAOD, SSA, and heating rate. The column AAOD, the fraction of absorption (1 - SSA) at $1 \mathrm{~km}$, and the heating rate at $1 \mathrm{~km}$ are 16, 50, and $17 \%$ higher, respectively, in the M01 simulation (domain average) than in the benchmark M10_SN simulation. The difference in absorption between the two simulations is attributed to two effects: the M01 simulation has (1) higher absorption by coating materials (lens effect) and (2) lower BC mass concentrations due to efficient wet removal processes (which decreased absorption) than the M10_SN simulation because the M01 simulation assumes internal mixing for all BC particles. These effects on absorption partly cancel each other because of their opposite signs (Stier et al., 2006; Matsui et al., 2013a). Because the former effect is larger than the latter effect in this study, the absorption in the M01 simulation is larger than that in the benchmark simulation.

Column AAOD is high over both northern and southern China (Fig. 8a). We calculated the absorption enhancement ratio by the lens effect for the M10_SN and M10_N simulations (Fig. 8b). In calculating the AAOD values with the assumption of externally mixed BC particles, all of the internally mixed $\mathrm{BC}$ particles are separated into $\mathrm{BC}$ (externally mixed) and non-BC (BC-free) particles. The absorption enhancement ratio is estimated to be about $50-60 \%$ and 
Table 4. Period- and domain-averaged optical and radiative parameters at noon.

\begin{tabular}{lllrrrrrrrrr}
\hline Parameter & Unit & Layer & M10_SN & M10_N & M08_SN & M06_SN & M04_SN & M01_SN & M01_N & M01_S & M01 \\
\hline AOD & - & Column & 0.311 & 0.246 & 0.311 & 0.312 & 0.311 & 0.309 & 0.244 & 0.312 & 0.246 \\
AAOD & - & Column & 0.0152 & 0.0138 & 0.0152 & 0.0160 & 0.0163 & 0.0183 & 0.0176 & 0.0183 & 0.0176 \\
SSA & - & PBL* & 0.930 & 0.921 & 0.930 & 0.927 & 0.925 & 0.910 & 0.894 & 0.911 & 0.895 \\
Heating rate & K day $^{-1}$ & PBL* & 0.424 & 0.395 & 0.425 & 0.443 & 0.454 & 0.513 & 0.492 & 0.513 & 0.494 \\
Downward flux & W m$^{-2}$ & Surface & -34.9 & -28.4 & -35.0 & -35.7 & -35.7 & -37.4 & -31.5 & -37.5 & -31.5 \\
\hline
\end{tabular}

*PBL, planetary boundary layer.
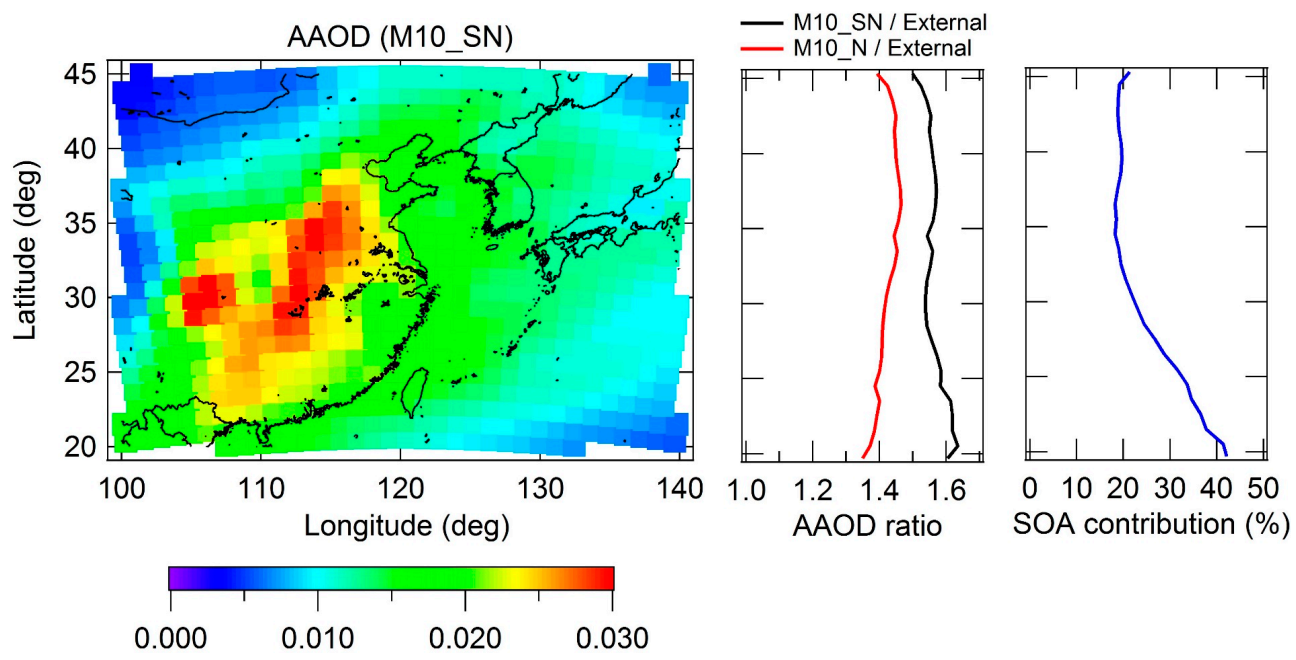

Figure 8. (a) The period- and domain-averaged column AAOD in the M10_SN simulation. (b) The latitudinal dependence of mean AAOD values in the M10_SN (black) and M10_N (red) simulations normalized by the column AAOD calculated by assuming externally mixed BC particles (External). In the External calculation, all of the internally mixed BC particles are separated into BC (externally mixed) and non-BC (BC-free) particles. (c) The latitudinal dependence of the contribution of SOA processes to the absorption enhancement by coating materials. The contribution is calculated from two column AAOD differences: the fraction of the AAOD difference between the M10_SN and M10_N simulations (M10_SN - M10_N) relative to the AAOD difference between the M10_SN simulation and the external calculation (M10_SN External).

$40 \%$ in the M10_SN and M10_N simulations, respectively (Fig. 8b). Because the absorption enhancement ratio is about $100 \%$ in the M01_SN simulation (not shown), the simulation without $\mathrm{BC}$ mixing states (internally mixed treatment for all particles) overestimates the absorption enhancement by a factor of 2 . The contribution of SOA processes (the difference in AAOD between M10_SN and M10_N) to the total absorption enhancement is about $20 \%$ over northern East Asia and about 20-40\% over southern East Asia (Fig. 8c). A reason of this latitudinal dependency is a higher OA / BC mass ratio over southern East Asia (Fig. S4 in the Supplement).

The difference in SSA between the benchmark and M01 simulations is caused by both BC aging and SOA processes. The treatment of $\mathrm{BC}$ mixing state increases SSA by 0.05 over northern China $\left(30-45^{\circ} \mathrm{N}\right)$ (Fig. 9a), where BC concentrations are high (Fig. S4 in the Supplement). The treatment of SOA processes is estimated to increase SSA by 0.03 at latitudes of $30-40^{\circ} \mathrm{N}$, where both $\mathrm{BC}$ and $\mathrm{OA}$ concentrations are high, mainly due to the enhancement of the scattering coefficient (Fig. 9b).

The difference in the heating rate by aerosols between the benchmark and M01 simulations is caused by two opposite effects. The treatment of the $\mathrm{BC}$ mixing state decreases the heating rate by $0.3 \mathrm{~K} \mathrm{~d}^{-1}$, mainly over northern China (30$40^{\circ} \mathrm{N}$ ), due to the reduction of absorption (Fig. 9c). SOA processes increase the heating rate by $0.1 \mathrm{~K} \mathrm{~d}^{-1}$ over central and southern China (20-35 N, Fig. 9d), where OA concentrations are high, because SOA processes increase the multiple scattering of radiation and the lens effect (Fig. 8c), both of which can enhance absorption.

The difference in the downward solar flux at the surface between the benchmark and M01 simulations is also caused by two opposite effects. SOA processes decrease the downward flux at the surface by $15 \mathrm{~W} \mathrm{~m}^{-2}$, with a maximum decrease over southern China (20-30 N, Fig. 9f), where OA concentrations are high. The treatment of $\mathrm{BC}$ mixing state increases the flux by $5 \mathrm{~W} \mathrm{~m}^{-2}$, with a maximum increase over central China (Fig. 9e). The increase is attributed to 


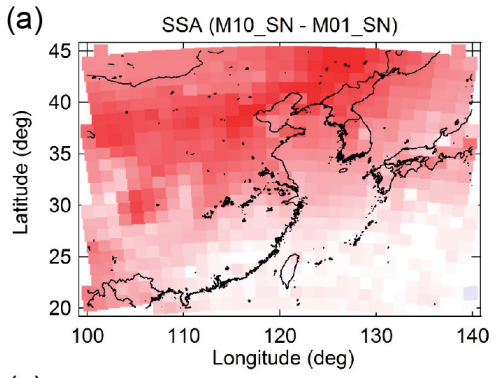

(c)
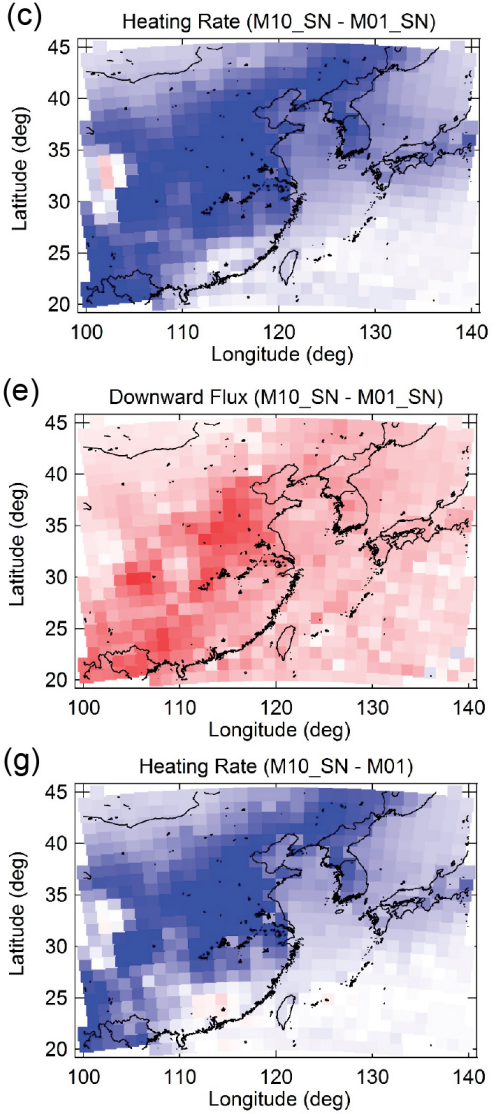

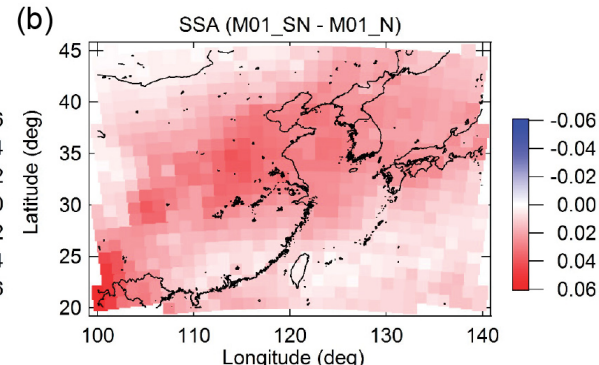

(d)
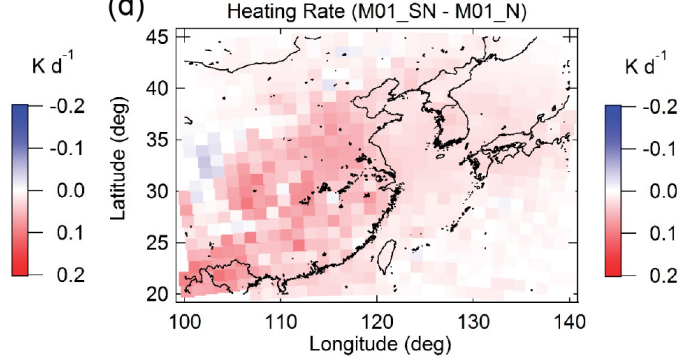

(f)
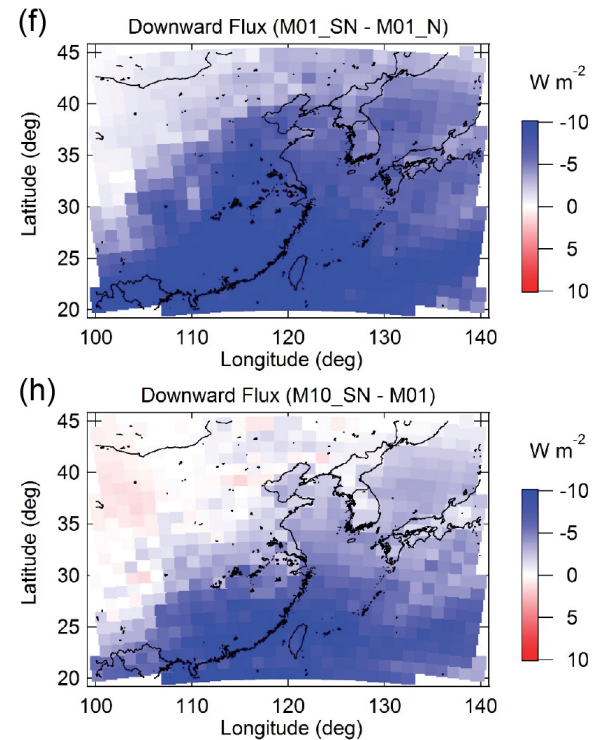

Figure 9. The period-averaged impacts of (left panels) BC aging and (right panels) SOA on SSA at $1 \mathrm{~km}$ (a and b), the heating rate by aerosols at $1 \mathrm{~km}$ (c and $\mathbf{d})$, and the change in the downward solar flux by aerosols at the surface (e and $\mathbf{f})$. The contributions of BC aging and SOA are estimated from the difference between the M10_SN and M01_SN simulations and between the M01_SN and M01 simulations, respectively. In the bottom two panels, the combined effects of BC aging and SOA (the difference between the M10_SN and M01 simulations) are also shown for (g) the heating rate by aerosols and (h) the change in the downward solar flux by aerosols at the surface. The period-averaged values are calculated offline using the data at 12:00 LT (03:00 UTC) between 24 March and 26 April.

reduced absorption in the benchmark simulation that leads to increased multiple scattering of radiation and downward surface flux.

The spatial distributions of the combined effects of BC aging and SOA differ markedly between the heating rate and the downward flux. The cooling effect of the atmosphere $(\sim 1 \mathrm{~km})$ is seen over northern China $\left(30-40^{\circ} \mathrm{N}\right)$ and over the Asian continent (Fig. 9g), whereas the negative radiative impact at the surface is seen over southern China $\left(20-30^{\circ} \mathrm{N}\right)$ and over the western Pacific (Fig. 9h). Because the impact of each process on each radiative parameter has a large latitudinal dependence (Fig. 9c-f), the total effects also have large latitudinal dependences. Positive and negative impacts are seen for both the heating rate and the downward flux, although the warming effect at around $25^{\circ} \mathrm{N}$ (Fig. 9g) and the positive downward flux over northern China (Fig. 9h) are not very large.

Aerosol optical and radiative parameters in the M08_SN, M06_SN, and M04_SN simulations are generally similar to those in the benchmark M10_SN simulation, although the 
Indirect effect

(CCN)

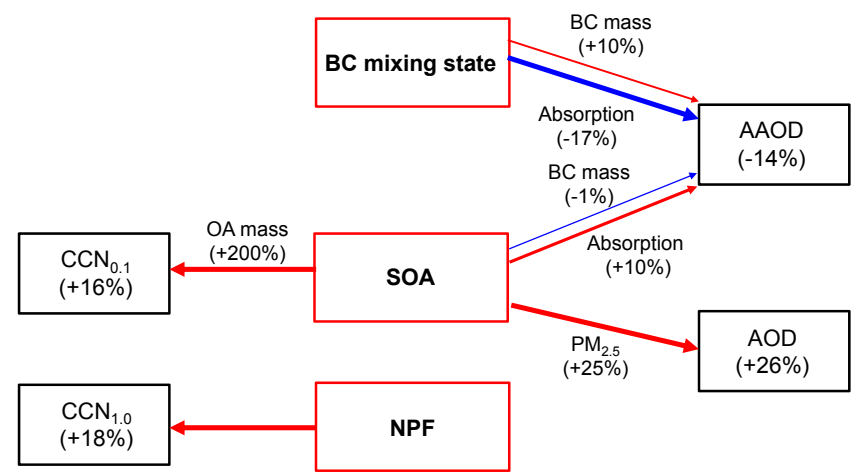

Figure 10. Summary of the sensitivity of the mass and number concentrations and optical and radiative parameters of aerosols to NPF, $\mathrm{BC}$ aging, and SOA. The red (blue) lines indicate positive (negative) impacts on individual aerosol parameters (black boxes). The impact of NPF is calculated from the difference between the M01_N and M01 simulations. The impact of SOA is calculated from the difference between the M10_SN and M10_N simulations. The impact of $\mathrm{BC}$ aging is the difference in each parameter between when the $\mathrm{BC}$ mixing state is resolved (the M10_SN simulation) and when the average mixing state is used (all $\mathrm{BC}$ particles are assumed to be internally mixed) (the M01_SN simulation). The change in BC mass concentrations is due to the change in BC hygroscopicity (mixing state) and resulting wet removal processes. The change in absorption is mainly due to the change in the lens effect. The percentages shown in black boxes are calculated from the difference between the M10_SN and M01 simulations.

performance deteriorates as the number of $\mathrm{BC}$ mixing state bins is decreased. The M06_SN and M04_SN simulations can explain 70-85 and $65-75 \%$ of the total BC mixing state effect (the difference in aerosol optical and radiative parameters between the M10_SN and M01_SN simulations; Table 4). These results suggest that the simulations with four or more mixing state bins could generally explain the actual $\mathrm{BC}$ mixing state effect reasonably well in terms of aerosol optical and radiative parameters in the boundary layer.

The NPF sensitivity of all the optical and radiative parameters examined in this study is small (Table 4). However, because NPF increases CCN concentrations (Sect. 3.3), this process may be of great importance in terms of the indirect effects of aerosols. SOA may also be important in estimating indirect effects because of the large sensitivity of SOA to $\mathrm{CCN}$ concentrations (Sect. 3.3). A simulation with a higher grid resolution is necessary to resolve fine-scale clouds and to evaluate indirect effects accurately. This type of study will be important in the future, but it is beyond the scope of this study.

The sensitivities of the mass, number, size distribution, and optical and radiative parameters of aerosols to NPF, BC aging, and SOA processes (discussed in Sects. 3.3 and 3.4) are shown in Fig. 10. The impact (positive or negative) and the relative importance of each process markedly differ between the parameters. We calculated these complicated responses for the first time using a detailed aerosol model that could explicitly and simultaneously represent important physical and chemical processes of aerosols. Because these responses have large spatial and temporal dependences, further applications are needed to more thoroughly understand the importance of individual aerosol processes.

\section{Summary and conclusions}

We developed an aerosol module, Aerosol Two-dimensional bin module for foRmation and Aging Simulation (ATRAS), and implemented it into the WRF-Chem/MOSAIC model. This module can represent important physical and chemical processes (NPF, BC aging, and SOA) that control the number concentrations, size distributions, and mixing states of aerosols in the atmosphere. ATRAS uses a total of 128 aerosol bins (at maximum). A two-dimensional bin representation is used for particles with dry diameters from $40 \mathrm{~nm}$ to $10 \mu \mathrm{m}$ in diameter to resolve both aerosol sizes and BC mixing states $(12 \times 10$ bins). Particles with diameters from 1 to $40 \mathrm{~nm}$ are resolved using additional eight size bins to calculate NPF.

We applied ATRAS-MOSAIC to the East Asian region in the spring of 2009, where and when aerosol mass and number concentrations and their spatial and temporal variations were evaluated in detail by both aircraft and surface measurements. The performance of ATRAS-MOSAIC was similar to or better than that of our previous WRF-Chem/MOSAIC simulations.

We examined the sensitivity of the mass, number, size distributions, and optical and radiative parameters of aerosols to NPF, BC aging (resolution of BC mixing state), and SOA processes by comparing the simulation results with (128 bins) and without (12 bins, assuming internally mixed particles) these processes. SOA processes increased $\mathrm{PM}_{2.5}$ and OA mass concentrations by 25 and $200 \%$, respectively (period- and domain-averaged values in the boundary layer). $\mathrm{BC}$ mass concentrations were increased by $10-15 \%$ by the treatment of the $\mathrm{BC}$ mixing state (Fig. 10).

$\mathrm{CCN}_{1.0}$ and $\mathrm{CCN}_{0.1}$ concentrations in the boundary layer were increased by 18 and $16 \%$, respectively, by both NPF and SOA processes. We found a clear north-south contrast between the impacts of NPF and SOA processes on $\mathrm{CCN}$ concentrations. NPF increased $\mathrm{CCN}$ concentrations at higher supersaturations (smaller particles) over northern East Asia, whereas SOA increased CCN concentrations at lower supersaturations (larger particles) over southern East Asia (Fig. 10). These processes will be important for the evaluation of the indirect effects of aerosols.

The detailed treatment of $\mathrm{BC}$ mixing state reduced the absorption coefficient because the absorption enhancement 
(due to the lens effect) was overestimated by a factor of 2 in the simulation without the treatment of the $\mathrm{BC}$ mixing state (i.e., when internal mixing of $\mathrm{BC}$ particles is assumed) (Fig. 10). The absorption enhancement ratio by the lens effect was about $60 \%$ in our simulation over East Asia. SOA processes increased both scattering and absorption coefficients (by the lens effect) (Fig. 10). The contribution of SOA processes to the total absorption enhancement was estimated to be $20 \%$ over northern East Asia and 20-40\% over southern East Asia.

$\mathrm{BC}$ aging processes decreased the heating rate at $1 \mathrm{~km}$ by $0.3 \mathrm{~K} \mathrm{~d}^{-1}$ and increased the downward flux at the surface by $5 \mathrm{~W} \mathrm{~m}^{-2}$, mainly over northern China, where BC concentrations were high. SOA processes increased the heating rate at $1 \mathrm{~km}$ by $0.1 \mathrm{~K} \mathrm{~d}^{-1}$ and decreased the downward flux at the surface by $15 \mathrm{~W} \mathrm{~m}^{-2}$, mainly over southern China, where OA concentrations were high. As a result, the spatial distributions of the combined effects of $\mathrm{BC}$ aging and SOA processes differ substantially between the heating rate and the downward flux.

Sensitivity simulations showed that the simulations with four or more mixing state bins could generally explain the actual BC mixing state effect reasonably well in terms of BC mass concentrations and aerosol optical and radiative parameters. Therefore, simulations with four mixing state bins may be reasonable for global applications by considering the balance between accuracy and computational cost. On the other hand, as the results are improved (approaching to the simulation with 10 mixing state bins) with increasing the number of mixing state bins, simulations with a sufficient number of mixing state bins may be necessary when we focus on the detailed information of $\mathrm{BC}$ mixing state.

For further improvements of our model, a nucleation parameterization considering the contribution of organic vapors to nucleation (Metzger et al., 2010) may be useful. Lowvolatility organic vapors, brown carbon, and OA formation in the aerosol phase will also be key factors for the model improvement of OA formation and its radiative effect (Liu et al., 2012; Feng et al., 2013). Including the formation of ice nuclei is another important step for studies on aerosol-cloud interactions. Extending BC mixing state treatments to dust particles may be the key to more realistic simulations of ice nuclei concentrations and their formation pathways.

ATRAS-MOSAIC has the potential to be a benchmark module for aerosol microphysical and chemical processes. The module can be used to understand which processes and parameters should be represented in detail and which ones can be simplified in predicting the mass, number, size distributions, and optical and radiative parameters of aerosols. The module can also be used to examine complicated interactions between aerosol processes, such as the impact of SOA on NPF and on BC aging and removal. The detailed aerosol model will be a useful tool for understanding the complicated and nonlinear climatic responses of aerosol processes to the change in meteorological conditions and emissions of chemical species in the future.

\section{The Supplement related to this article is available online at doi:10.5194/acp-14-10315-2014-supplement.}

Acknowledgements. This work was supported by the Ministry of Education, Culture, Sports, Science, and Technology and the Japan Society for the Promotion of Science (MEXT/JSPS), KAKENHI grant numbers 26740014 and 23221001 and the GRENE Arctic Climate Change Research Project. This work was also supported by the strategic international cooperative program of the Japan Science and Technology Agency, by the global environment research fund of the Ministry of the Environment, Japan (2A-1101 and 2-1403), and the Alliance for Global Sustainability project of the University of Tokyo. The authors thank Nobuhiro Moteki (University of Tokyo), Nobuyuki Takegawa (University of Tokyo, now at Tokyo Metropolitan University), Akinori Takami (National Institute for Environmental Studies), Yugo Kanaya (Japan Agency for MarineEarth Science and Technology), Soonchang Yoon (Seoul National University), and Sang-Woo Kim (Seoul National University) for providing the measurement data during the A-FORCE campaign. For some of the simulations, we used the supercomputer systems at the University of Tokyo and Japan Agency for Marine-Earth Science and Technology. J. D. Fast was supported by the US Department of Energy (DOE) Atmospheric System Research (ASR) program under contract DE-AC06-76RLO 1830 at PNNL. PNNL is operated for the US DOE by Battelle Memorial Institute.

Edited by: B. Ervens

\section{References}

Abdul-Razzak, H. and Ghan, S. J.: A parameterization of aerosol activation: 2. Multiple aerosol types, J. Geophys. Res., 105, 68376844, doi:10.1029/1999JD901161, 2000.

Aquila, V., Hendricks, J., Lauer, A., Riemer, N., Vogel, H., Baumgardner, D., Minikin, A., Petzold, A., Schwarz, J. P., Spackman, J. R., Weinzierl, B., Righi, M., and Dall'Amico, M.: MADE-in: a new aerosol microphysics submodel for global simulation of insoluble particles and their mixing state, Geosci. Model Dev., 4, 325-355, 2011.

Bohren, C. F. and Huffman, D. R.: Absorption and Scattering of Light by Small Particles, 530 pp., John Wiley, Hoboken, N. J., 1998.

Bond, T. C., Habib, G., and Bergstrom, R. W.: Limitations in the enhancement of visible light absorption due to mixing state, $\mathrm{J}$ Geophys. Res., 111, D20211, doi:10.1029/2006JD007315, 2006.

Bond, T. C., Doherty, S. J., Fahey, D. W., Forster, P. M., Berntsen, T., DeAngelo, B. J., Flanner, M. G., Ghan, S., Kärcher, B., Koch, D., Kinne, S., Kondo, Y., Quinn, P. K., Sarofim, M. C., Schultz, M. G., Schulz, M., Venkataraman, C., Zhang, H., Zhang, S., Bellouin, N., Guttikunda, S. K., Hopke, P. K., Jacobson, M. Z., Kaiser, J. W., Klimont, Z., Lohmann, U., Schwarz, J. P., Shindell, D., Storelvmo, T., Warren, S. G., and Zender, C. S.: 
Bounding the role of black carbon in the climate system: A scientific assessment, J. Geophys. Res.-Atmos., 118, 5380-5552, doi:10.1002/jgrd.50171, 2013.

Carter, W. P. L.: Documentation of the SAPRC-99 Chemical Mechanism for VOC Reactivity Assessment, Report to the California Air Resources Board. College of Engineering, Center for Environmental Research and Technology, University of California at Riverside, CA, Contracts 92-329 and 95-308, available at: http://www.cert.ucr.edu/ carter/reactdat.htm, 2000.

Donahue, N. M., Robinson, A. L., Stanier, C. O., and Pandis, S. N.: Coupled partitioning, dilution, and chemical aging of semivolatile organics, Environ. Sci. Technol., 40, 2635-2643, 2006.

Easter, R. C., Ghan, S. J., Zhang, Y., Saylor, R. D., Chapman, E. G., Laulainen, N. S., Abdul-Razzak, H., Leung, L. R., Bian, X., and Zaveri, R. A.: MIRAGE: Model description and evaluation of aerosols and trace gases, J. Geophys. Res., 109, D20210, doi:10.1029/2004JD004571, 2004.

Fahey, K. M. and Pandis, S. N.: Optimizing model performance: Variable size resolution in cloud chemistry modeling, Atmos. Environ., 35, 4471-4478, 2001.

Fast, J. D., Gustafson Jr., W. I., Easter, R. C., Zaveri, R. A., Barnard, J. C., Chapman, E. G., Grell, G. A., and Peckham, S. E.: Evolution of ozone, particulates, and aerosol direct radiative forcing in the vicinity of Houston using a fully coupled meteorology-chemistry-aerosol model, J. Geophys. Res., 111, D21305, doi:10.1029/2005JD006721, 2006.

Feng, Y., Ramanathan, V., and Kotamarthi, V. R.: Brown carbon: a significant atmospheric absorber of solar radiation?, Atmos. Chem. Phys., 13, 8607-8621, doi:10.5194/acp-13-8607-2013, 2013.

Ghan, S. J., Abdul-Razzak, H., Nenes, A., Ming, Y., Liu, X., Ovchinnikov, M., Shipway, B., Meskhidze, N., Xu, J., and Shi, X.: Droplet nucleation: Physically-based parameterizations and comparative evaluation, J. Adv. Model. Earth Syst., 3, M10001, doi:10.1029/2011MS000074, 2011.

Grell, G. A., Peckham, S. E., Schmitz, R., McKeen, S. A., Frost, G., Skamarock, W. C., and Eder, B: Fully coupled "online" chemistry within the WRF model, Atmos. Environ., 39, 6957-6975, 2005.

Guenther, A., Karl, T., Harley, P., Wiedinmyer, C., Palmer, P. I., and Geron, C.: Estimates of global terrestrial isoprene emissions using MEGAN (Model of Emissions of Gases and Aerosols from Nature), Atmos. Chem. Phys., 6, 3181-3210, doi:10.5194/acp-63181-2006, 2006.

Hallquist, M., Wenger, J. C., Baltensperger, U., Rudich, Y., Simpson, D., Claeys, M., Dommen, J., Donahue, N. M., George, C., Goldstein, A. H., Hamilton, J. F., Herrmann, H., Hoffmann, T., Iinuma, Y., Jang, M., Jenkin, M. E., Jimenez, J. L., Kiendler-Scharr, A., Maenhaut, W., McFiggans, G., Mentel, Th. F., Monod, A., Prévôt, A. S. H., Seinfeld, J. H., Surratt, J. D., Szmigielski, R., and Wildt, J.: The formation, properties and impact of secondary organic aerosol: current and emerging issues, Atmos. Chem. Phys., 9, 5155-5236, doi:10.5194/acp-9-51552009, 2009.

Heald, C. L., Jacob, D. J., Park, R. J., Russell, L. M., Huebert, B. J., Seinfeld, J. H., Liao, H., and Weber, R. J.: A large organic aerosol source in the free troposphere missing from current models, Geophys. Res. Lett., 32, L18809, doi:10.1029/2005GL023831, 2005.
Heald, C. L., Coe, H., Jimenez, J. L., Weber, R. J., Bahreini, R., Middlebrook, A. M., Russell, L. M., Jolleys, M., Fu, T.-M., Allan, J. D., Bower, K. N., Capes, G., Crosier, J., Morgan, W. T., Robinson, N. H., Williams, P. I., Cubison, M. J., DeCarlo, P. F., and Dunlea, E. J.: Exploring the vertical profile of atmospheric organic aerosol: comparing 17 aircraft field campaigns with a global model, Atmos. Chem. Phys., 11, 12673-12696, doi:10.5194/acp-11-12673-2011, 2011.

IPCC: Summary for Policymakers, in: Climate Change 2013: The Physical Science Basis. Contribution of Working Group I to the Fifth Assessment Report of the Intergovernmental Panel on Climate Change, edited by: Stocker, T. F., Qin, D., Plattner, G.-K., Tignor, M., Allen, S. K., Boschung, J., Nauels, A., Xia, Y., Bex, V., and Midgley, P. M., Cambridge University Press, Cambridge, United Kingdom and New York, NY, USA, 2013.

Jacobson, M. Z.: Development and application of a new air pollution modeling system-II. Aerosol module structure and design, Atmos. Environ., 31, 131-144, 1997.

Jacobson, M. Z.: A physically-based treatment of elemental carbon optics: Implications for global direct forcing of aerosols, Geophys. Res. Lett., 27, 217-220, doi:10.1029/1999GL010968, 2000.

Jacobson, M. Z: Strong radiative heating due to the mixing state of black carbon in atmospheric aerosols, Nature, 409, 695-697, 2001.

Jacobson, M. Z., Turco, R. P., Jensen, E. J., and Toon, O. B.: Modeling coagulation among particles of different composition and size, Atmos. Environ., 28, 1327-1338, 1994.

Jimenez, J. L., Canagaratna, M. R., Donahue, N. M., Prevot, A. S. H., Zhang, Q., Kroll, J. H., DeCarlo, P. F., Allan, J. D., Coe, H., Ng, N. L., Aiken, A. C., Docherty, K. S., Ulbrich, I. M., Grieshop, A. P., Robinson, A. L., Duplissy, J., Smith, J. D., Wilson, K. R., Lanz, V. A., Hueglin, C., Sun, Y. L., Tian, J., Laaksonen, A., Raatikainen, T., Rautiainen, J., Vaattovaara, P., Ehn, M., Kulmala, M., Tomlinson, J. M., Collins, D. R., Cubison, M. J., Dunlea, E. J., Huffman, J. A., Onasch, T. B., Alfarra, M. R., Williams, P. I., Bower, K., Kondo, Y., Schneider, J., Drewnick, F., Borrmann, S., Weimer, S., Demerjian, K., Salcedo, D., Cottrell, L., Griffin, R., Takami, A., Miyoshi, T., Hatakeyama, S., Shimono, A., Sun, J. Y., Zhang, Y. M., Dzepina, K., Kimmel, J. R., Sueper, D., Jayne, J. T., Herndon, S. C., Trimborn, A. M., Williams, L. R., Wood, E. C., Middlebrook, A. M., Kolb, C. E., Baltensperger, U., and Worsnop, D. R.: Evolution of organic aerosols in the atmosphere, Science, 326, 1525-1529, 2009.

Kanakidou, M., Seinfeld, J. H., Pandis, S. N., Barnes, I., Dentener, F. J., Facchini, M. C., Van Dingenen, R., Ervens, B., Nenes, A., Nielsen, C. J., Swietlicki, E., Putaud, J. P., Balkanski, Y., Fuzzi, S., Horth, J., Moortgat, G. K., Winterhalter, R., Myhre, C. E. L., Tsigaridis, K., Vignati, E., Stephanou, E. G., and Wilson, J.: Organic aerosol and global climate modelling: a review, Atmos. Chem. Phys., 5, 1053-1123, doi:10.5194/acp-5-1053-2005, 2005.

Kanaya, Y., Taketani, F., Komazaki, Y., Liu, X., Kondo, Y., Sahu, L. K., Irie, H., and Takashima, H.: Comparison of black carbon mass concentrations observed by Multi-Angle Absorption Photometer (MAAP) and Continuous Soot-Monitoring System (COSMOS) on Fukue Island and in Tokyo, Japan, Aerosol Sci. Technol., 47, 1-10, 2013. 
Kondo, Y., Sahu, L., Moteki, N., Khan, F., Takegawa, N., Liu, X., Koike, M., and Miyakawa, T.: Consistency and traceability of black carbon measurements made by laser-induced incandescence, thermal-optical transmittance, and filter-based photoabsorption techniques, Aerosol Sci. Technol., 45, 295-312, 2011.

Koo, B., Ansari, A. S., and Pandis, S. N.: Integrated approaches to modeling the organic and inorganic atmospheric aerosol components, Atmos. Environ., 37, 4757-4768, 2003.

Korhola, T., Kokkola, H., Korhonen, H., Partanen, A.-I., Laaksonen, A., Lehtinen, K. E. J., and Romakkaniemi, S.: Reallocation in modal aerosol models: impacts on predicting aerosol radiative effects, Geosci. Model Dev., 7, 161-174, 2014.

Kuang, C., McMurry, P. H., McCormick, A. V., and Eisele, F. L.: Dependence of nucleation rates on sulfuric acid vapor concentration in diverse atmospheric locations, J. Geophys. Res., 113, D10209, doi:10.1029/2007JD009253, 2008.

Kulmala, M., Pirjola, L., and Mäkelä, J. M.: Stable sulphate clusters as a source of new atmospheric particles, Nature, 404, 66-69, 2000.

Kulmala, M., Vehkamäki, H., Petäjä, T., Dal Maso, M., Lauri, A., Kerminen, V.-M., Birmili, W., and McMurry, P. H.: Formation and growth rates of ultrafine atmospheric particles: A review of observations, J. Aerosol Sci., 35, 143-176, 2004.

Kulmala, M., Lehtinen, K. E. J., and Laaksonen, A.: Cluster activation theory as an explanation of the linear dependence between formation rate of $3 \mathrm{~nm}$ particles and sulphuric acid concentration, Atmos. Chem. Phys., 6, 787-793, doi:10.5194/acp-6-787-2006, 2006

Kulmala, M., Riipinen, I., Sipilä, M., Manninen, H. E., Petäjä, T., Junninen, H., Dal Maso, M., Mordas, G., Mirme, A., Vana, M., Hirsikko, A., Laakso, L., Harrison, R. M., Hanson, I., Leung, C., Lehtinen, K. E. J., and Kerminen, V.-M.: Toward direct measurement of atmospheric nucleation, Science, 318, 89-92, 2007.

Liu, J., Horowitz, L. W., Fan, S., Carlton, A. G., and Levy II, H.: Global in-cloud production of secondary organic aerosols: Implementation of a detailed chemical mechanism in the GFDL atmospheric model AM3, J. Geophys. Res., 117, D15303, doi:10.1029/2012JD017838, 2012.

Lohmann, U. and Feichter, J.: Global indirect aerosol effects: a review, Atmos. Chem. Phys., 5, 715-737, doi:10.5194/acp-5-7152005, 2005.

Makkonen, R., Asmi, A., Korhonen, H., Kokkola, H., Järvenoja, S., Räisänen, P., Lehtinen, K. E. J., Laaksonen, A., Kerminen, V.M., Järvinen, H., Lohmann, U., Bennartz, R., Feichter, J., and Kulmala, M.: Sensitivity of aerosol concentrations and cloud properties to nucleation and secondary organic distribution in ECHAM5-HAM global circulation model, Atmos. Chem. Phys., 9, 1747-1766, doi:10.5194/acp-9-1747-2009, 2009.

Makkonen, R., Asmi, A., Kerminen, V.-M., Boy, M., Arneth, A., Hari, P., and Kulmala, M.: Air pollution control and decreasing new particle formation lead to strong climate warming, Atmos. Chem. Phys., 12, 1515-1524, doi:10.5194/acp-12-15152012, 2012.

Matsui, H., Koike, M., Takegawa, N., Kondo, Y., Griffin, R. J., Miyazaki, Y., Yokouchi, Y., and Ohara, T.: Secondary organic aerosol formation in urban air: Temporal variations and possible contributions from unidentified hydrocarbons, J. Geophys. Res., 114, D04201, doi:10.1029/2008JD010164, 2009a.
Matsui, H., Koike, M., Kondo, Y., Takegawa, N., Kita, K., Miyazaki, Y., Hu, M., Chang, S.-Y., Blake, D. R., Fast, J. D., Zaveri, R. A., Streets, D. G., Zhang, Q., and Zhu, T.: Spatial and temporal variations of aerosols around Beijing in summer 2006: Model evaluation and source apportionment, J. Geophys. Res., 114, D00G13, doi:10.1029/2008JD010906, 2009b.

Matsui, H., Koike, M., Kondo, Y., Takegawa, N., Fast, J. D., Pöschl, U., Garland, R. M., Andreae, M. O., Wiedensohler, A., Sugimoto, N., and Zhu, T.: Spatial and temporal variations of aerosols around Beijing in summer 2006: 2. Local and column aerosol optical properties, J. Geophys. Res., 115, D22207, doi:10.1029/2010JD013895, 2010.

Matsui, H., Koike, M., Kondo, Y., Takegawa, N., Wiedensohler, A., Fast, J. D., and Zaveri, R. A.: Impact of new particle formation on the concentrations of aerosols and cloud condensation nuclei around Beijing, J. Geophys. Res., 116, D19208, doi:10.1029/2011JD016025, 2011.

Matsui, H., Koike, M., Kondo, Y., Moteki, N., Fast, J. D., and Zaveri, R. A.: Development and validation of a black carbon mixing state resolved three-dimensional model: Aging processes and radiative impact, J. Geophys. Res.-Atmos., 118, 2304-2326, doi:10.1029/2012JD018446, 2013a.

Matsui, H., Koike, M., Takegawa, N., Kondo, Y., Takami, A., Takamura, T., Yoon, S., Kim, S.-W., Lim, H.-C., and Fast, J. D.: Spatial and temporal variations of new particle formation in East Asia using an NPF-explicit WRF-chem model: North-south contrast in new particle formation frequency, J. Geophys. Res.Atmos., 118, 11647-11663, doi:10.1002/jgrd.50821, 2013 b.

Matsui, H., Koike, M., Kondo, Y., Oshima, N., Moteki, N., Kanaya, Y., Takami, A., and Irwin, M.: Seasonal variations of Asian black carbon outflow to the Pacific: contribution from anthropogenic sources in China and biomass burning sources in Siberia and Southeast Asia, J. Geophys. Res.-Atmos., 118, 9948-9967, doi:10.1002/jgrd.50702, 2013c

Matsui, H., Koike, M., Kondo, Y., Takami, A., Fast, J. D., Kanaya, Y., and Takigawa, M.: Volatility basis-set approach simulation of organic aerosol formation in East Asia: implications for anthropogenic-biogenic interaction and controllable amounts, Atmos. Chem. Phys. Discuss., 14, 6203-6260, doi:10.5194/acpd-14-6203-2014, 2014.

Merikanto, J., Spracklen, D. V., Mann, G. W., Pickering, S. J., and Carslaw, K. S.: Impact of nucleation on global CCN, Atmos. Chem. Phys., 9, 8601-8616, doi:10.5194/acp-9-8601-2009, 2009.

Metzger, A., Verheggen, B., Dommen, J., Duplissy, J., Prevot, A. S. H., Weingartner, E., Riipinen, I., Kulmala, M., Spracklen, D. V., Carslaw, K. S., and Baltensperger, U.: Evidence for the role of organics in aerosol particle formation under atmospheric conditions, P. Natl. Acad. Sci. USA, 107, 6646-6651, 2010.

Moteki, N. and Kondo, Y.: Effects of mixing state on black carbon measurements by laser-induced incandescence, Aerosol Sci. Technol., 41, 398-417, 2007.

Moteki, N. and Kondo, Y.: Dependence of laser-induced incandescence on physical properties of black carbon aerosols: Measurements and theoretical interpretation, Aerosol Sci. Technol., 44, 663-675, 2010.

Moteki, N., Kondo, Y., Miyazaki, Y., Takegawa, N., Komazaki, Y., Kurata, G., Shirai, T., Blake, D. R., Miyakawa, T., and Koike, M.: Evolution of mixing state of black carbon particles: Aircraft 
measurements over the western Pacific in March 2004, Geophys. Res. Lett., 34, L11803, doi:10.1029/2006GL028943, 2007.

Moteki, N., Kondo, Y., Oshima, N., Takegawa, N., Koike, M., Kita, K., Matsui, H., and Kajino, M.: Size dependence of wet removal of black carbon aerosols during transport from the boundary layer to the free troposphere, Geophys. Res. Lett., 39, L13802, doi:10.1029/2012GL052034, 2012.

Oshima, N., Koike, M., Zhang, Y., and Kondo, Y.: Aging of black carbon in outflow from anthropogenic sources using a mixing state resolved model: 2. Aerosol optical properties and cloud condensation nuclei activities, J. Geophys. Res., 114, D18202, doi:10.1029/2008JD011681, 2009.

Oshima, N., Kondo, Y., Moteki, N., Takegawa, N., Koike, M., Kita, K., Matsui, H., Kajino, M., Nakamura, H., Jung, J. S., and Kim, Y. J.: Wet removal of black carbon in Asian outflow: Aerosol Radiative Forcing in East Asia (A-FORCE) aircraft campaign, J. Geophys. Res., 117, D03204, doi:10.1029/2011JD016552, 2012.

Ramanathan, V., Crutzen, P. J., Kiehl, J. T., and Rosenfeld, D.: Aerosols, climate, and the hydrological cycle, Science, 294, 2119-2124, 2001.

Reddington, C. L., Carslaw, K. S., Spracklen, D. V., Frontoso, M. G., Collins, L., Merikanto, J., Minikin, A., Hamburger, T., Coe, H., Kulmala, M., Aalto, P., Flentje, H., Plass-Dülmer, C., Birmili, W., Wiedensohler, A., Wehner, B., Tuch, T., Sonntag, A., O'Dowd, C. D., Jennings, S. G., Dupuy, R., Baltensperger, U., Weingartner, E., Hansson, H.-C., Tunved, P., Laj, P., Sellegri, K., Boulon, J., Putaud, J.-P., Gruening, C., Swietlicki, E., Roldin, P., Henzing, J. S., Moerman, M., Mihalopoulos, N., Kouvarakis, G., Ždímal, V., Zíková, N., Marinoni, A., Bonasoni, P., and Duchi, R.: Primary versus secondary contributions to particle number concentrations in the European boundary layer, Atmos. Chem. Phys., 11, 12007-12036, doi:10.5194/acp-11-12007-2011, 2011.

Schell, B., Ackermann, I. J., Hass, H., Binkowski, F. S., and Ebel, A.: Modeling the formation of secondary organic aerosol within a comprehensive air quality model system, J. Geophys. Res., 106, 28275-28293, doi:10.1029/2001JD000384, 2001.

Shrivastava, M., Fast, J., Easter, R., Gustafson Jr., W. I., Zaveri, R. A., Jimenez, J. L., Saide, P., and Hodzic, A.: Modeling organic aerosols in a megacity: comparison of simple and complex representations of the volatility basis set approach, Atmos. Chem. Phys., 11, 6639-6662, doi:10.5194/acp-11-6639-2011, 2011.

Simmel, M. and Wurzler, S.: Condensation and activation in sectional cloud microphysical models, Atmos. Res., 80, 218-236, 2006.

Skamarock, W. C., Klemp, J. B., Dudhia, J., Gill, D. O., Barker, D. M., Wang, W., and Powers, J. G.: A description of the advanced research WRF version 3, NCAR Tech. Note, NCAR/TN475+STR, Natl. Cent. Atmos. Res., Boulder, Colo, 2008.

Spracklen, D. V., Carslaw, K. S., Kulmala, M., Kerminen, V.-M., Mann, G. W., and Sihto, S.-L.: The contribution of boundary layer nucleation events to total particle concentrations on regional and global scales, Atmos. Chem. Phys., 6, 5631-5648, doi:10.5194/acp-6-5631-2006, 2006.

Spracklen, D. V., Carslaw, K. S., Kulmala, M., Kerminen, V.-M., Sihto, S.-L., Riipinen, I., Merikanto, J., Mann, G. W., Chipperfield, M. P., Wiedensohler, A., Birmili, W., and Lihavainen, H.: Contribution of particle formation to global cloud condensation nuclei concentrations, Geophys. Res. Lett., 35, L06808, doi:10.1029/2007GL033038, 2008.
Spracklen, D. V., Carslaw, K. S., Merikanto, J., Mann, G. W., Reddington, C. L., Pickering, S., Ogren, J. A., Andrews, E., Baltensperger, U., Weingartner, E., Boy, M., Kulmala, M., Laakso, L., Lihavainen, H., Kivekäs, N., Komppula, M., Mihalopoulos, N., Kouvarakis, G., Jennings, S. G., O’Dowd, C., Birmili, W., Wiedensohler, A., Weller, R., Gras, J., Laj, P., Sellegri, K., Bonn, B., Krejci, R., Laaksonen, A., Hamed, A., Minikin, A., Harrison, R. M., Talbot, R., and Sun, J.: Explaining global surface aerosol number concentrations in terms of primary emissions and particle formation, Atmos. Chem. Phys., 10, 4775-4793, doi:10.5194/acp-10-4775-2010, 2010.

Spracklen, D. V., Jimenez, J. L., Carslaw, K. S., Worsnop, D. R., Evans, M. J., Mann, G. W., Zhang, Q., Canagaratna, M. R., Allan, J., Coe, H., McFiggans, G., Rap, A., and Forster, P.: Aerosol mass spectrometer constraint on the global secondary organic aerosol budget, Atmos. Chem. Phys., 11, 12109-12136, doi:10.5194/acp-11-12109-2011, 2011.

Stier, P., Seinfeld, J. H., Kinne, S., Feichter, J., and Boucher, O.: Impact of nonabsorbing anthropogenic aerosols on clearsky atmospheric absorption, J. Geophys. Res., 111, D18201, doi:10.1029/2006JD007147, 2006.

Streets, D. G., Bond, T. C., Carmichael, G. R., Fernandes, S. D., Fu, Q., He, D., Klimont, Z., Nelson, S. M., Tsai, N. Y., Wang, M. Q., Woo, J.-H., and Yarber, K. F.: An inventory of gaseous and primary aerosol emissions in Asia in the year 2000, J. Geophys. Res., 108, 8809, doi:10.1029/2002JD003093, 2003.

Takami, A., Miyoshi, T., Shimono, A., and Hatakeyama, S.: Chemical composition of fine aerosol measured by AMS at Fukue Island, Japan, during APEX period, Atmos. Environ., 39, 49134924, 2005.

Takami, A., Miyoshi, T., Shimono, A., Kaneyasu, N., Kato, S., Kajii, Y., and Hatakeyama, S.: Transport of anthropogenic aerosols from Asia and subsequent chemical transformation, J. Geophys. Res., 112, D22S31, doi:10.1029/2006JD008120, 2007.

Takegawa, N., Moteki, N., Koike, M., Oshima, N., and Kondo, Y.: Condensation particle counters combined with a low-pressure impactor for fast measurement of mode-segregated aerosol number concentration, Aerosol Sci. Technol., 47, 1059-1065, 2013.

Tsimpidi, A. P., Karydis, V. A., Zavala, M., Lei, W., Molina, L., Ulbrich, I. M., Jimenez, J. L., and Pandis, S. N.: Evaluation of the volatility basis-set approach for the simulation of organic aerosol formation in the Mexico City metropolitan area, Atmos. Chem. Phys., 10, 525-546, doi:10.5194/acp-10-525-2010, 2010.

van der Werf, G. R., Randerson, J. T., Giglio, L., Collatz, G. J., Mu, M., Kasibhatla, P. S., Morton, D. C., DeFries, R. S., Jin, Y., and van Leeuwen, T. T.: Global fire emissions and the contribution of deforestation, savanna, forest, agricultural, and peat fires (19972009), Atmos. Chem. Phys., 10, 11707-11735, doi:10.5194/acp10-11707-2010, 2010.

Wexler, A. S., Lurmann, F. W., and Seinfeld, J. H.: Modelling urban and regional aerosols. Part I: Model development, Atmos. Environ., 28, 531-546, 1994.

Yu, F., Luo, G., and Ma, X.: Regional and global modeling of aerosol optical properties with a size, composition, and mixing state resolved particle microphysics model, Atmos. Chem. Phys., 12, 5719-5736, doi:10.5194/acp-12-5719-2012, 2012. 
Zaveri, R. A., Easter, R. C., and Wexler, A. S.: A new method for multicomponent activity coefficients of electrolytes in aqueous atmospheric aerosols, J. Geophys. Res., 110, D02201, doi:10.1029/2004JD004681, 2005a.

Zaveri, R. A., Easter, R. C., and Peters, L. K.: A computationally efficient Multicomponent Equilibrium Solver for Aerosols (MESA), J. Geophys. Res., 110, D24203, doi:10.1029/2004JD005618, 2005b.

Zaveri, R. A., Easter, R. C., Fast, J. D., and Peters, L. K.: Model for Simulating Aerosol Interactions and Chemistry (MOSAIC), J. Geophys. Res., 113, D13204, doi:10.1029/2007JD008782, 2008.
Zhang, Q., Jimenez, J. L., Canagaratna, M. R., Allan, J. D., Coe, H., Ulbrich, I., Alfarra, M. R., Takami, A., Middlebrook, A. M., Sun, Y. L., Dzepina, K., Dunlea, E., Docherty, K., DeCarlo, P. F., Salcedo, D., Onasch, T., Jayne, J. T., Miyoshi, T., Shimono, A., Hatakeyama, S., Takegawa, N., Kondo, Y., Schneider, J., Drewnick, F., Borrmann, S., Weimer, S., Demerjian, K., Williams, P., Bower, K., Bahreini, R., Cottrell, L., Griffin, R. J., Rautiainen, J., Sun, J. Y., and Zhang, Y., M.: Ubiquity and dominance of oxygenated species in organic aerosols in anthropogenically influenced Northern Hemisphere midlatitudes, Geophys. Res. Lett., 34, L13801, doi:10.1029/2007GL029979, 2007. 